\title{
What native speaker judgments tell us about the grammaticalization of a progressive aspectual marker in Dutch ${ }^{1}$
}

MONIQUE FLECKEN

Abstract

This paper focuses on native speaker judgments of a construction in Dutch that functions as a progressive aspectual marker (aan het X zijn, referred to as aan het-construction) and represents an event as in progression at the time of speech. The method was chosen in order to investigate how native speakers assess the scope and conditions of use of a construction which is in the process of grammaticalization. It allows for the inclusion of a large group of participants of different age groups and an investigation of potential age-related differences. The study systematically covers a range of temporal variables that were shown to be relevant in elicitation and corpus-based studies on the grammaticalization of progressive aspect constructions. The results provide insights into the selectional preferences and constraints of the aan het-construction in contemporary Dutch, as judged by native speakers, and the extent to which they correlate with production tasks.

\section{Introduction}

This paper reports on an empirical study on processes of grammaticalization. It focuses on selection of a particular construction in Standard Dutch as spoken in the Netherlands (aan het Xzijn, referred to as the aan het-construction) which expresses a progressive aspectual meaning. Using an acceptability judgment task, the study investigates under what conditions this construction is judged as appropriate in expressing the aspectual distinction "event is ongoing".

The current study sets out to investigate the assumption that the aan hetconstruction may be systematically expanding in its range of use and attempts to picture the course taken in the process of grammaticalization. By means of an analysis of speakers' acceptability judgments, the paper provides an overview of both the contexts where selection of the aan het-construction is 
considered most appropriate, as well as those where selection of the construction is inappropriate, giving an indication of the factors that drive the expansion of the aan het-construction in contemporary Dutch. The selection of the different variables tested in the acceptability judgment task is based on production studies looking at the extent to which aspectual markers are used in different languages. Furthermore, the analysis includes differences in judgments between native speakers of different ages as a possible indication of the rate of expansion.

As this paper focuses on the grammaticalization of an aspectual construction, it is, first of all, important to state how grammaticalization is defined. Bybee et al. (1994: 4) view grammaticalization as the process by which grammatical morphemes gradually develop out of lexical morphemes or combinations of lexical elements with grammatical or lexical elements. The meaning and application of these evolving grammatical morphemes is of greater generality than their original lexical meaning, with use expanding to a wider range of contexts. In particular, this expansion occurs from prototypical contexts of use to less prototypical contexts, resulting in a wider applicability of the morpheme (see Section 1.3.1.). The meaning of the grammatical marker becomes more abstract but it is often the case that some of the original lexical meaning remains (Givón 1973, cited in Bybee et al. 1994; Hopper and Traugott 2003). This generalization of meaning goes hand in hand with a reduction in form, in particular phonological reduction.

There are certain common features that can be derived from processes of grammaticalization of aspectual markers crosslinguistically. One example is that progressive constructions often derive from expressions involving locative elements (Comrie 1976; Heine et al. 1991; Bybee et al. 1994; Bertinetto et al. 2000), as in the case of the English progressive to be $+V$-ing form (Jespersen 1954; Vlach 1981; Bybee et al. 1994). ${ }^{2}$ In the first stage of grammaticalization the lexical (spatial) character of the locative preposition was lost. The Dutch aan het-construction also consists of a locative element (preposition aan 'at/on'), which no longer has a true spatial meaning (Boogaart 1991, 1999; Ebert 2000; Lemmens 2005). Considering these analogies and the functional similarity between the Dutch aan het-construction and the English progressive form, it is hypothesized that the aan het-construction is (becoming) a grammatical marker of progressive aspect. The next section investigates the aspectual category of the progressive in more detail.

\subsection{Progressive aspect}

Starting with core temporal relations, a grammatical aspectual marker denotes the relation between the Topic Time (TT), the time that is being talked about 


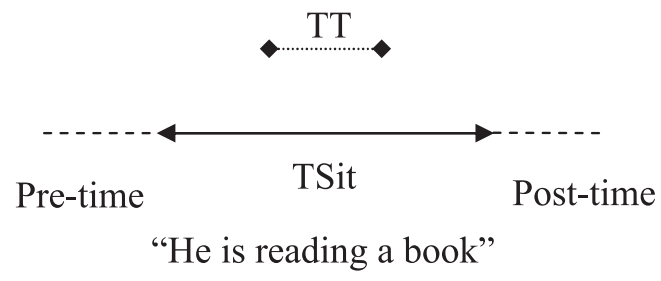

Figure 1. Time-relational structure of the progressive aspect

(i.e., the time for which the assertion holds), and the Time of Situation (Tsit), the infinite or unspecified time period of the event (cf. Klein 1994). Progressive aspect specifically relates to a time interval where the Topic Time is fully included within the Time of Situation (Figure 1).

In other words, in time-relational terms, the time interval (TT) that the speaker refers to is fully incorporated within the Time of Situation (The TSit is the total time of "he-read-a book", which in this case is unspecified). This specifies what is meant by an "inside" view of the situation, which is a much quoted metaphor for the progressive aspect (e.g., Comrie 1976; Leech 2004). ${ }^{3}$ The function of progressive aspect is thus to express the ongoingness of a particular situation at a given TT interval. The TT is not instantaneous since the time interval at issue is extended given this perspective.

As mentioned above, a fully grammaticalized progressive marker is given with the English to be $+V$-ing construction. In English, a true opposition in meaning has come about between the unmarked simple verb form and the verb marked with -ing. Bybee labels this difference in meaning between the marked and the unmarked form grammaticalization of zero (Bybee et al. 1994; Bybee 1994). The functions ascribed to the simple present tense in English are a result of the grammaticalization of the specific meaning of the progressive in particular contexts. Example 1a shows that the predicate marked by -ing has the prototypical progressive meaning, that is, it presents a situation as ongoing for the interval at issue. One of the meanings that the simple form may express is habituality (1b). It can also represent a state or characteristic of a person over an unlimited period of time (definition similar to Comrie 1976) (as in Example (1c)).

(1) a. He was reading (when they entered the room)

b. He reads the newspaper (every morning)

c. He reads books (general statement)

Although the relevant time interval is fully within the time of situation, the beginning and end of the overall situation with its pre- and post-time is always implied (1a). If not, there would not be any difference between the time intervals referred to by means of the simple form and those referred to by means of 


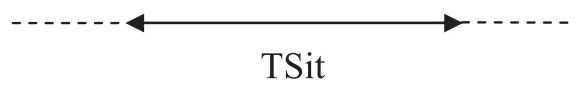

"I love chocolate"

Figure 2. Time-relational structure of 0 -state verbs

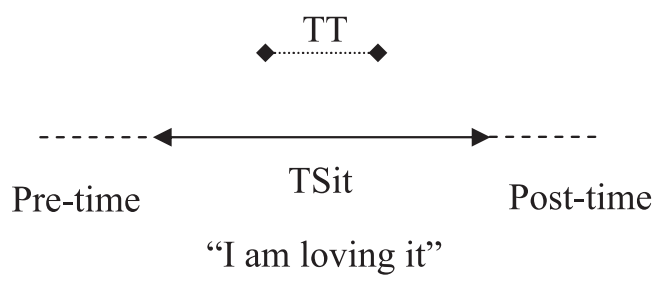

Figure 3. Time-relational structure of 0-state verbs with progressive marking

the progressive. For example, no pre- or post-time is implied by the 0 -state verb to love (cf. Klein 1994; a "state" in the Vendler (1957) classification) in Figure 2 (I-love-chocolate). It makes no sense in this case to make a claim about a specific Topic Time (TT) on the TSit axis. Regardless of the placement of TT, the meaning of TSit (I-love-chocolate) remains unchanged. In other words, there are no possible TT-contrasts (cf. Klein 1994).

If the lexical content of a clause allows for a time interval preceding and following the specific Time of Situation (a pre- / post-time), it makes sense to make a claim about a specific Topic Time (time for which the assertion holds) along the TSit axis. If a TSit inherently implies a change of state, for example, through either the temporal semantics of the clause, or world knowledge, it is suited for use of a progressive. This condition is expressed by the notion of a Topic Time contrast (Klein 1994), and all verbs allow for this contrast, in principle, with the exception of 0-state verbs (cf. Klein 1994), which express unbounded states.

If we now turn to the example in Figure 3, which is a famous advertising slogan, we see that the meaning of the 0 -state verb "to love" is changed to allow for TT-contrasts, i.e., in the sense of a 1-state verb (e.g., "to enjoy") and thus gives a limited time interval for which the statement holds: It is assumed that there is a state for which "not enjoy" holds, the pre- and post-time of "to love" is implied.

What the above examples show is that use of the progressive is allowed only in cases with a TT-contrast. The aspectual form will thus encode the ongoingness of a particular Topic Time, linked to a Time of Situation that is bounded. In this sense, sentences such as cats are mammals cannot undergo a progressive operation. Apart from the pre-condition of possibilities for TT-contrasts, 
the English progressive marker is subject to few selectional restrictions. The TT-interval that an expression with -ing relates to may be placed anywhere along the TSit axis (he is finishing up; they are approaching the summit), due to the high level of grammaticalization of the form. It is hypothesized that markers of progressive aspect that are in earlier stages of grammaticalization are subject to more constraints with respect to temporal variables that are relevant for use of such aspectual forms.

The next section deals with the focus of the paper: the Dutch progressive aan het-construction. The aim of the present study is to identify and test the variables that determine acceptability of the Dutch progressive aan het-form in its current stage of grammaticalization, as judged by native speakers.

\subsection{The case of Dutch}

Dutch has several constructions that are used to express that a situation is ongoing in explicit terms. In addition to the aan het-construction, which is the focus of the present paper, the other options are constructions that include the posture verbs zitten/liggen/staan te plus an infinitive, the motion verb lopen te plus an infinitive or the adjectival construction bezig te plus infinitive. Use of the Dutch posture verb constructions (vs. aan het) is discussed, for example, in Lemmens (2005) and Ebert (2000) (corpus studies) and they conclude that use of the posture verb constructions is constrained by the lexical meaning of the three basic locational verbs involved. Empirical studies (von Stutterheim et al. 2009) which elicit event descriptions of short ongoing situations (presented in video clips) have found that the aan het-construction is used much more frequently than the posture verb constructions to express ongoingness $(4.7 \%$ zitten/staan te vs. $26 \%$ aan het of a total of 911 utterances (von Stutterheim et al. 2009)), presumably because of the semantically constrained use of the posture verb constructions. The data show that, although the meaning conveyed by both types of constructions is interchangeable in many cases, speakers have preferences for using one rather than the other type of aspectual form in given contexts, with more constraints on use of posture verbs. This indicates that the aan het-construction is ahead in grammaticalization and functions independent of its inherent lexical (locative) meaning, as opposed to the posture verb constructions. For this reason the focus of the current study is placed on speakers' judgments of the aan het-construction versus the unmarked simple verb form only.

The Dutch progressive marker under investigation is a periphrastic construction and it consists of the locative preposition aan 'at'/'on', the definite article het 'the' plus a nominalized infinitival form of the verb (see e.g., König and van der Auwera 1994; Boogaart 1991; Lemmens 2005) (example in (2)). 


\section{(2) Ik ben aan het fietsen \\ 'I am at-the-cycle'}

As mentioned above, this aspectual marker expresses ongoingness, but there are constraints with respect to placement of the TT on the time axis, as well as the verb types and verbal-predicate (temporal) semantics that allow use of the aan het-construction. The current study aims at identifying the temporal properties of situations that allow selection of this progressive, in contrast to those that do not. The following paragraph gives a brief review of some of the literature on the aan het-construction.

In typological terms, the Dutch language is viewed as a non-aspect language. Studies dealing with the aan het-construction (e.g., Boogaart 1991; 1999) state that this is a locative construction with a progressive-like meaning (1999: 167) but with a limited range of application. Booij (2008) considers the aan het-construction as a constructional idiom that has the function of expressing progressive aspect. However, the form is described as a lexical unit, an idiom expressing a "durational event" (p. 9). The present study investigates the question of the type and range of selectional restrictions and the extent to which the aan het-construction may be on its way to becoming a full-fledged grammatical element in the Dutch system - a path that may perhaps lead to an even more phonologically and perhaps orthographically reduced form with a more abstract meaning and an increasing loss of restrictions.

Several experimental studies have been carried out, looking at temporal factors determining use of the progressive in a range of languages, some of which included Dutch (e.g., von Stutterheim and Carroll 2006; Carroll et al. 2008; von Stutterheim et al. 2009). ${ }^{4}$ These studies show, first of all, that use of the aan het-construction is relatively frequent for specific types of situations, but its use is still very much dependent on a restricted set of temporal properties. Crosslinguistically, it was found that situations that involve a change in place of a person or object from one place to another (motion events), represent an interesting case with regard to the use of progressive aspect. Speakers of languages that do not have grammaticalized progressive aspect tend to take a holistic viewpoint and mention the endpoint of the motion event (von Stutterheim and Carroll 2006). However, when motion events are viewed as in progression, they are typically segmented into an inceptive, intermediate and terminative phase in languages in which progressive aspect is grammaticalized, and any of these phases constitutes a reportable event. Speakers select an interval within the time of situation, as discussed above (Section 1.1). When presented with a motion event that focuses on the intermediate stage of the event, as in the video clips used in the study (scene shows a car going along a country road with a possible goal (a village) in the distance), speakers of e.g., English or Standard Arabic tend to select this phase (a car is travelling along a road) and do not 
typically go on to relate to a possible terminal phase or endpoint (going to a village). Preliminary results show that Dutch speakers may segment motion events into phases and use the progressive to relate to the intermediate phase of the event (though this is not frequent); however, they do not use the aspectual construction when the terminative phase is in focus (as in the vehicle is approaching the traffic lights). Use is more likely to occur with motion events that focus the intermediate phase (and are not goal-directed) as well as manner of motion (e.g., wandelen 'taking a walk') (Carroll et al. 2008; von Stutterheim et al. 2009). These findings shed light on the nature of the intervals that are selected (within TSit) when using progressive aspect in a particular language. This variable is also empirically tested in the acceptability judgment task in relation to motion events.

\subsection{Relevant temporal variables applied in the experimental design}

In the current study, several temporal variables relevant for use of forms expressing ongoingness are identified based on previous studies. These variables are systematically manipulated across and within six versions of the acceptability judgment task. This section will discuss each variable and show how it is controlled for within the experimental design. Table 1 below provides an overview of the variables tested with the sections in which they are treated in the study below.

1.3.1. TT-placement. Studies on the grammaticalization of the progressive aspect in English (be $+V$-ing) claim that, in the early stages, use was limited to situations taking place in the here-and-now, in the narrow sense of right now. Bybee et al. (1994) claim that the here-and-now is the prototypical context for using forms expressing ongoingness during the early stages of grammaticalization (1994: 137). It is hypothesized that, during the course of grammaticalization, use expands from situations in which the time of assertion (TT) overlaps

Table 1. Variables controlled for within the experimental design

\begin{tabular}{ll}
\hline TT-placement & Paragraph 1.3.1: Temporal contexts \\
TT-contrast & Paragraph 1.3.2: \\
Situation types: & - Type A situations (to swim) \\
No qualitative change of an entity & - Type B situations ( to mould $x$ ) \\
+ qualitative change of an entity & - Motion events $+/$ - endpoint \\
Change in place $+/$ - endpoint & - 0-state verbs \\
TT-contrast & Paragraph 1.3.2: Motion verbs plus endpoint \\
Duration & Paragraph 1.3.3 \\
Age &
\end{tabular}


with the time of utterance (TU) ("what one is doing right now", TT includes TU) to situations occurring in the past, where TT is placed before TU). The possibilities for placement of the Topic Time on the time axis are thus expanded. In English, for example, placement of TT before TU is not a constraint on use of the progressive form.

In the current study on Dutch, the first research question that will be empirically addressed and the first variable that will be tested by means of the acceptability judgment task is as follows:

Do situations that are anchored in the here-and-now (the Topic Time includes the Time of Utterance), in the narrow sense outlined above, still present the only (or the best) context of use for the aan het-construction? Can the Dutch form apply to situations that extend beyond the here-and-now in the narrow sense, as in Caspar was reading a book or Katja is practising law?

In order to investigate this question within the present study, this variable was manipulated within the acceptability judgment task so as to cover three different temporal contexts. The participants in the study are asked to judge the suitability of the aan het-construction combined with a variety of situation types (see 1.3.2.) in these three temporal contexts.

The here-and-now temporal context places the Time of Utterance within the Topic Time, rendering a here-and-now reading. The past tense temporal context places the Time of Utterance after the Topic Time, rendering a reference to a situation in the past. The habitual temporal context involves situations where the Topic Time referred to covers several occurrences of the time of situation (TSit) (see Table 2).

The Examples (3)-(5) below illustrate how the three temporal contexts are brought about in the acceptability judgment task (the examples show an item of situation type A - pianospelen 'to play the piano'; see 1.3.2 for an overview of the different situation types). The words or phrases in bold lead to the temporal interpretation "here-and-now" versus "past" versus "habitual". The

Table 2. Temporal contexts

\begin{tabular}{|l|l|l|}
\hline $\begin{array}{l}\text { "Here-and-now - context" } \\
\text { ONGOING EVENT- } \\
\text { RIGHT NOW }\end{array}$ & $\begin{array}{l}\text { "Past tense context" } \\
\text { ONGOING EVENT- } \\
\text { IN THE PAST }\end{array}$ & $\begin{array}{l}\text { "Habitual context" } \\
\text { HABITUAL EVENT- } \\
\text { ONGOING AT REPEATED } \\
\text { OCCASSIONS } \\
\begin{array}{l}\text { Present tense, event } \\
\text { temporally anchored in the } \\
\text { here-and-now } \\
\rightarrow \text { TT includes TU }\end{array}\end{array}$ \\
$\begin{array}{l}\text { Past tense, event temporally habitual event } \\
\text { anchored in the past }\end{array}$ & $\rightarrow$ TT is placed before TU \\
See Figure 4 & See Figure 5 & $\begin{array}{l}\rightarrow \text { TSits placed at several places } \\
\text { on the time axis, TT covers all } \\
\text { occurrences. } \\
\text { TU irrelevant } \\
\text { See Figure 6 }\end{array}$ \\
\hline
\end{tabular}




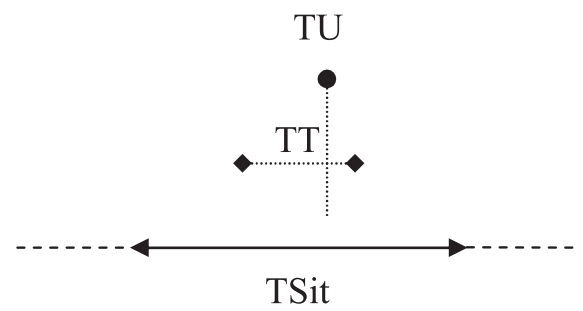

Figure 4. Here-and-now temporal context: Ongoing — right now

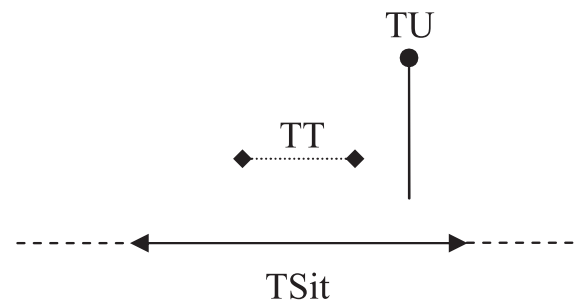

Figure 5. Past tense temporal context: Ongoing - in the past

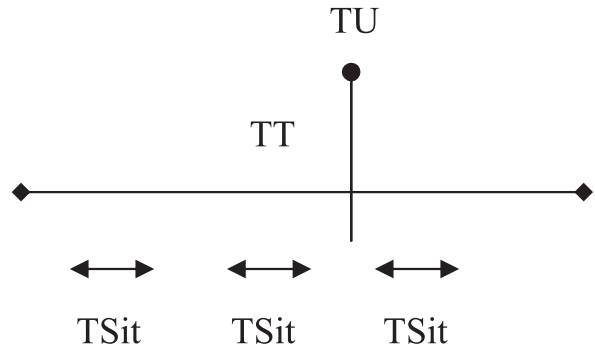

Figure 6. Habitual temporal context

question posed to the subject (aan het-form versus simple form: Wat ben je aan het doen? (Wat doe je?) is varied for each item between subjects.

(3) Here-and-now context:

Stel: Vandaag moet je de hele dag oefenen op de piano voor een optreden. Het klinkt best aardig en je gaat er al een tijdje helemaal in op. Op een gegeven moment gaat de telefoon. Een vriend vraagt: "Wat ben je nu aan het doen? /Wat doe je nu? " Je antwoordt:

a) Ik speel piano

b) Ik ben piano aan het spelen 
'Imagine: Today you have to practice for a piano performance. It sounds quite nice and you are totally absorbed in it. At a given time the phone rings. A friend asks: "What are you doing right now?"

a) I play the piano

b) I am piano at-the-play'

(4) Past tense context:

Stel: Vorig jaar heb je een keer opgetreden in de schouwburg en nu vertel je een vriend erover. Hij/zij vraagt: "Wat deed je vorig jaar dan in de schouwburg? /Wat was je vorig jaar dan aan het doen in de schouwburg?" Je antwoordt:

a) Ik speelde piano/Ik heb piano gespeeld

b) Ik was piano aan het spelen

'Imagine: Last year you performed in the Music hall and now you are telling a friend about this. He/she asks: "What did you do in the Music hall last year?" You answer:

a) I played the piano

b) I was piano at-the-play'

(5) Habitual context:

Stel: Je bent pianist van beroep en je speelt in een band. Jullie oefenen dagelijks en treden vaak op in het weekend. Je wordt op een dag gebeld door een telemarketeer die je allerlei vragen stelt. Hij wil onder andere weten welk beroep je uitoefent. Hij hoort ondertussen het geluid van de band die gewoon door repeteert, en vraagt: "Wat doet $u$ in het dagelijks leven? /Wat bent $u$ in het dagelijks leven aan het doen?". Je antwoordt:

a) Ik speel piano

b) Ik ben piano aan het spelen

'Imagine: You are a professional pianist and you play in a band. You practice daily and you usually have performances during weekends. One day you receive a phone call of a telemarketer who starts asking all kinds of questions. He would like to know about your profession, for example. In the background he can hear the sounds of the band, who is rehearsing, and he asks: "What do you do in daily life?" You answer:

a) I play the piano

b) I am piano-at-the-play'

The temporal reference frame "here-and-now" versus "past" versus "habitual" is established through a manipulation of the whole situation description, by means of adverbial phrases, adjectives and through contextual knowledge.

The overview of temporal contexts (Figure 2) presents a hypothetical order of strength in attracting use of an evolving progressive marker. The here-andnow context is claimed to be the prototypical context (cf. Bybee et al. 1994), whereas situations that do not give the possibility of a topic time contrast (TTcontrast) should pose a fundamental barrier. 
1.3.2. Situation types. Within the acceptability judgment task, a variety of different types of situations are described to the subject and he/she is asked to judge acceptability of the aan het-form versus the simple form for different items within the different groups of situation types. The distinction between the situation types described below is based on a number of experimental elicitation studies in which specific temporal features of situations were manipulated on a systematic basis in order to test their relevance for ongoingness marking in different languages (see for a description of the methodology von Stutterheim et al. 2009; Carroll et al. 2004). Within this framework, situation types are distinguished based on the nature of inherent temporal properties of the situation as shown in short video clips.

A large scale study on the use of progressive aspect in Italian, Dutch, French and Standard Arabic (Natale 2009; Carroll et al. 2008) led to the identification of situation types that are relevant for use in these languages since this aspectual perspective is not obligatory in Italian, French, or Dutch in any context. The study investigates the relevance of the situation type "activities" for use of the progressive in these different languages. The term "activity" Vendler (1957) is used for verbs that do not express a change in state / boundary of the event (e.g., to run, to write). It was claimed that these verb types (the label was originally used to cover the time schemata of verbs) are prototypical contexts for inflection with progressive aspect (Comrie 1976: Bybee et al. 1994) and represent the starting point for a possible process of grammaticalization (Bybee et al. 1994). In the study on Italian, French and Dutch (Natale 2009, Carroll et al. 2008), the broad category covered by the term "activities" was taken apart and a distinction was drawn between dynamic situations that show an inherent qualitative change leading to an effected entity (someone knitting something, sewing, painting, or moulding something) where the post time of the situation shows a resultant state (e.g., a moulded vase). This contrasts with situations involving someone swimming, surfing, singing etc. in which the post time of the situation involves no more than the cessation of the event (x stops swimming) The crosslinguistic comparison on factors that drive use of progressive aspect was based on situations of this kind presented in the form of video clips.

In the classification below, situation type A covers the latter set. They involve only 1 temporal interval (1-state situations, cf. Klein 1994) and no change of state is entailed. Type B situations involve agents acting on specific objects, thereby bringing about a salient qualitative change of the object involved, as indicated above. Situations that are typically expressed with "activity" verbs in English were thus divided into those that show changes of state leading to a resultant state (Type B), in contrast to those (Type A) that lead, when finished, to cessation only (stop surfing; stop swimming). Type B situations were divided into two subtypes: In addition to the first group listed above, 
Table 3. Situation types based on Natale (2009)

Situation types

Type A:

No qualitative change with respect to an entity/1-state situation e.g., to swim, to play ball, to play billiards

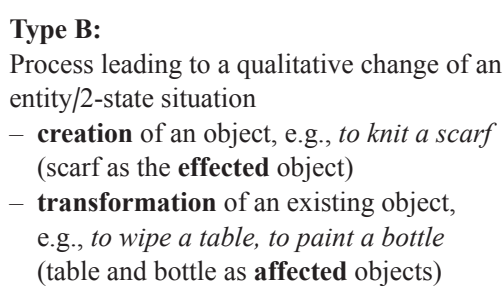

Type B:

ge of an entity/2-state situation

creation of an object, e.g., to knit a scarf (scarf as the effected object) e.g., to wipe a table, to paint a bottle (table and bottle as affected objects)

the second group of Type B situations do not involve the creation, but rather the transformation of an object. Examples of those are painting a bottle; tidying up a room and breaking a cup, with the bottle, room and cup as affected objects. Situations within type B express an inherent qualitative change and involve 2-states (cf. Klein 1994) (see Table 3).

As mentioned above, use of aspectual distinctions that encode an event as ongoing is not obligatory in any context in Italian, French or Dutch. The results of the study show that speakers of Italian and French have a clear preference to use the progressive form when describing stimuli (video clips) presenting situations listed under Type B, in contrast to type A situations, where use is less frequent in both languages (Carroll et al. 2008). These findings are interpreted as follows: a process leading to the creation of a specific object (a resultant state) gives a measure for "progression", given the contrast between the evolving states and the envisaged post state. This analysis provides empirical evidence showing that the aspectual means used in Italian and French have a clear progressive component in the present phase of grammaticalization.

Besides the two types of situations listed in Table 3, the acceptability judgment task also includes a group of items that involve 0-state verbs (cf. Klein 1994; "states" cf. Vendler 1957. Examples: weten, houden van 'know', 'love'). This group of items is included to test the relevance of the variable TT-contrast for judgments of the aan het-construction: In 1.1 it was exemplified for English that a lack of TT-contrasts is a logical constraint on the use of progressive aspect, and the acceptability judgment task sets out to test the strength of this variable for the Dutch aan het-construction.

Two types of motion event descriptions are also included in the task - those that include reference to a specific endpoint, and those that do not - in order to investigate the use of an aan het-construction with a situation that involves a change in place and the relevance of a holistic viewpoint ("endpoint") for acceptability judgments (as described in 1.2).

Figure 7 below shows a hypothetical order for the different situation types for the acceptability of the aan het-construction. This order is based on previous 
Native speaker judgments of an aspectual marker in Dutch 491

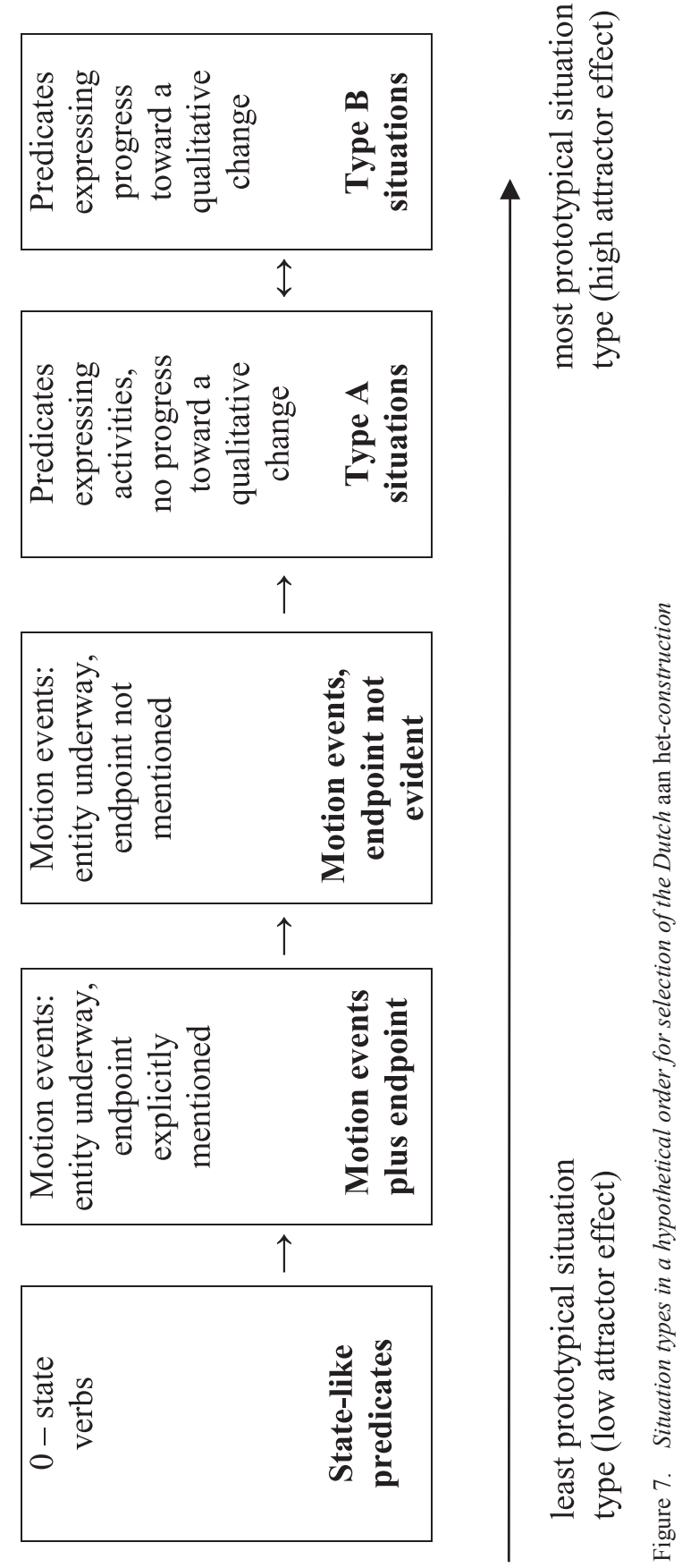


findings discussed above with respect to the relevance of TT-contrasts, inherent changes of state and endpoints of motion events. Examples (6-11) exemplify how one specific item representing each situation type (in the here-andnow context) was described in the judgment task.

(6) 0-state verbs (here-and-now context):

Stel: Je zit nu in de klas, en de lerares vraagt of iemand iets van honden weet. Uitvoerig begin je je buurvrouw over je hond te vertellen. De lerares komt niet meer boven het lawaai uit, en vraagt je dus: "Hee, wat ben jij nu aan het doen? /Wat doe jij nu?" Je probeert haar duidelijk te maken dat het erg belangrijk is wat je te vertellen hebt:

a) Ja maar, ik ben een hond aan het hebben!

b) Ja maar, ik heb een hond!

'Imagine: You are in class right now and the teacher asks if anyone has any knowledge about dogs. You start an elaborate conversation with your neighbor about your dog. The teacher is bothered by the noise and asks: "What are you doing right now?" You try to explain to her that you have important things to say:

a) Yes, but I am a dog at-the-have!

b) Yes, but I have a dog!'

(7) Motion events with entity underway (here-and-now context) plus endpoint (possible arrival at interval in the future):

- Long duration:

Stel: Je gaat voor een week op vakantie naar Frankrijk. Het is vandaag zaterdag, je zit in de auto en hebt nog een lange reis voor de boeg. Om de rit wat aangenamer te maken, ga je telefoneren. De persoon aan de andere kant van de lijn vraagt: "Wat ben je nu aan het doen? /Wat doe je nu?" Je zegt:

a) Ik rijd naar Frankrijk

b) Ik ben naar Frankrijk aan het rijden

'Imagine: You are going to France for a week's holiday. It is Saturday, you are in the car and you have a long journey ahead of you. To make the trip more comfortable, you start making phone calls. The person at the other end asks: "What are you doing right now?" You say:

a) I drive to France

b) I am to France at-the-drive'

- Short duration:

Stel: Je bent vandaag met vrienden in een zwembad. Je staat op de rand van het bad, klaar om te springen, terwijl een vriend net onder die rand doorzwemt. Hij kijkt omhoog en vraagt: "Wat ben jij nu aan het doen? /Wat doe je nu?" Terwijl je je afzet, roep je:

a) Kijk uit! Ik spring in het water!

b) Kijk uit! Ik ben in het water aan het springen! 
'Imagine: You are in a pool with friends. You are standing on the edge of the pool, ready to jump, while a friend is swimming right beneath you. He looks up and asks: "What are you doing now?" As you jump, you shout:

a) Watch out! I jump in the water

b) Watch out! I am in the water at-the-jump'

(8) Motion events minus endpoint (here-and-now context):

Stel: Het is vandaag lekker weer en je fietst een stukje over de dijk. Tijdens het fietsen gaat je telefoon en de persoon aan de andere kant van de lijn vraagt:

"Wat ben jij nu aan het doen? /Wat doe je nu?"

a) Ik ben aan het fietsen

b) Ik fiets

'Imagine: The weather is nice and you are cycling along the dyke. While cycling, your phone rings and the person at the other end asks: "What are you doing right now?"

a) I am at-the-cycle

b) I cycle'

(9) Type A situations (here-and-now context):

Stel: Vandaag moet je de hele dag oefenen op de piano voor een optreden. Het klinkt best aardig en je gaat er al een tijdje helemaal in op. Op een gegeven moment gaat de telefoon. Een vriend vraagt: "Wat ben je nu aan het doen? /Wat doe je nu?". Je antwoordt:

a) Ik speel piano

b) Ik ben piano aan het spelen

'Imagine: Today you have to practice for a piano performance. It sounds quite nice and you are totally absorbed in it. At a given time the phone rings. A friend asks: "What are you doing right now?"

a) I play the piano

b) I am piano at-the-play'

(10) Type B situations - effected object (here-and-now context):

Stel: Vanmiddag zit je thuis op de bank te breien. Je werkt al een tijdje aan een sjaal voor je opa. Op een gegeven moment gaat je telefoon. Het is een vriend(in) en hij/zij vraagt je: "Heb je zin om mee naar de bios te gaan? Of wat doe je nu? /Wat ben je nu aan het doen?" Je vertelt:

a) Ik brei een sjaal

b) Ik ben een sjaal aan het breien

'Imagine: This afternoon you are at home, knitting a scarf. You have been working on the scarf, which is a gift for your grandfather, for a while now. At a given time the phone rings. A friend asks: "Do you feel like going to the cinema? Or what are you doing right now?"

a) I knit a scarf

b) I am a scarf at-the-knit' 
(11) Type B situations — affected object (here-and-now context): ${ }^{5}$

Stel: Je bent bezig met de afwas, maar er glipt iets uit je handen. Je probeert het nog op te vangen, maar het is te laat. Ondertussen heeft je vriend(in) je gestuntel opgemerkt en hij/zij vraagt: "Wat doe je nu? /Wat ben je nu aan het doen?". Je zegt:

a) Ik breek een bord

b) Ik ben een bord aan het breken

'Imagine: You are busy doing the dishes but suddenly something slips through your hands. You try to catch it, but it is too late. Meanwhile your friend has noticed what is going on and asks: "What are you doing right now?"

a) I break a plate

b) I am a plate at-the-break'

The questions with respect to the situation types for Dutch are, first of all, in which of the situation types is the aan het-construction chosen most frequently (with a particular focus on Type A versus Type B situations (cf. Carroll et al. 2008)? Secondly, do speakers of Dutch when making judgments show similar preferences to those found in speech production with respect to motion events (see 1.2: cf. von Stutterheim et al. 2009)? Thirdly, are Dutch speakers, in the judgment task, reluctant to apply the progressive when situations do not allow for a TT-contrast (situations described with 0 -state verbs)? These and other questions constitute the motivation behind the division into situation types depicted in Figure (7).

1.3.3. Duration. As Example (7) above shows, another variable manipulated within the task concerns duration, which is coupled with the time interval factor what is now the case. In motion events in the present context this entails the presence of a long rather than a short trajectory on the journey to a possible goal (driving to France versus jumping in the water, for example) where reaching the endpoint in the latter situation type holds for the interval what is now the case but not in the former one). The role of duration was tested through the addition of adverbial phrases in investigating as to whether a long duration may elicit a higher acceptability of the aan het-construction in combination with motion events. ${ }^{6}$

1.3.4. Age. An external variable that is taken into account in this study is age in order to gain a more complete picture of preferred and non-preferred contexts of use of the aan het-construction in contemporary Dutch. Differences in judgments between native speakers of different generations may reflect an expansion of the range of contexts in which the form is considered acceptable. However, this needs to be tested further by an inclusion of a wider range of age groups and other means, e.g., elicitation experiments. 
Within all age groups, the number of males and females is counterbalanced, in an attempt to control for a possible gender effect.

\section{Methodology}

The acceptability judgment task was administered to 113 participants in three age groups (14-18 year-olds: 44 participants, 20-30 year-olds: 36 participants, 50 year-olds and above (eldest participant is 79 years old): 33 participants). The participants are asked to choose between a sentence with a simple form and one including an aan het-construction in different contexts and for different situation types. ${ }^{7}$ As with all judgment tasks, the core assumption is that there is no objective right or wrong answer: Acceptability judgments depend solely on native speaker's linguistic intuitions and their preferred choice out of a variety of options.

Besides making a choice for one of the two constructions, participants were also asked to ascribe a value between 1 and 5 ( 1 = completely unacceptable, 5 = completely acceptable) to the answer that was not chosen. Thus, this value guages the answer not chosen for acceptability in the specific context. ${ }^{8}$

In total there are 40 items per judgment task (plus 2 practice items) (for a full list of items see Table 4 and an example judgment task in Appendix A). Each item consists of a brief description of a situation (around 2-4 sentences) and the instruction to imagine being in this situation. The question that follows is a direct question involving the simple form or the progressive form asking: What are you doing? (In Dutch: Wat doe je? vs. Wat ben je aan het doen?) (Example 12). In the past tense context the question was in the past tense.

(12) Kies het beste antwoord uit (door de letter a) of b) te omcirkelen) en geef aan hoe acceptabel je DE ANDERE OPTIE vindt (dus de optie die je niet gekozen hebt), op een schaal van 1 tot $5^{*}$, door ook het geschikte cijfer te omcirkelen.

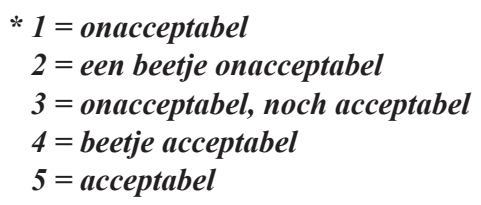

1) Stel: Op een herfstachtige dag loop je even lekker door het bos. Na een tijdje lopen gaat je telefoon en iemand vraagt: "Wat ben je nu aan het doen?" Je zegt:

a) Ikwandel

b) Ik ben aan het wandelen

1-2-3-4-5

'Choose the best answer (by circling letter a or b). Also indicate how acceptable you find THE OTHER OPTION (so the option you did not choose), on a scale from 1 to $5^{*}$, by also circling the appropriate number. 


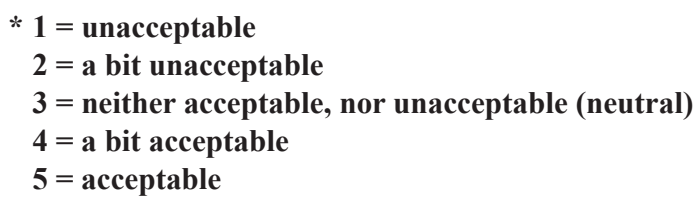

'1) Imagine: On a rainy day, you are walking through the forest. After a while, your phone rings and somebody asks you: "What are you doing right now?". You answer:
a) I walk
b) I am walking
1-2-3-4-5

The variables manipulated across and within six versions of the judgment task are as follows: the order of the items, the order of the answer-options (that is simple form-option or aan het-form option listed first), use of the simple form or aan het-form in the question put to the participant (this was manipulated for each item across versions). Furthermore, across versions the temporal context (as described above in 1.3., the here-and-now context, past tense context and habitual context) is changed for each item. This means that each subject was presented with all of the identified situation types in all three temporal contexts (both temporal context and situation type are within-subject variables) (see Table 4 for an overview of the items for the different situation types).

Besides this division into situation types and the manipulation of the temporal contexts, the variable duration (long vs. short duration) is controlled for within the group of motion verbs plus an endpoint (see 1.3.3).

Finally, as mentioned above, age also represents a factor considered in the analyses and three age groups were covered in the study (with gender balanced within the groups).

The form of the two answer options is kept simple: The predicate consists of a subject ( $i k$ 'I') plus a finite lexical verb or a finite form of to be plus the aan het-form and the relevant lexical verb. The answer options for Type B situations always include a direct object (since this is hypothesized to be the relevant crucial feature of the predicate), and the predicates with motion verbs plus endpoint always include an adjunct (expressing the endpoint). ${ }^{9}$ This variation raises a question with respect to the status of predicates with or without adjuncts in combination with the simple form or the aan het-form. In the current design, predicates without adjuncts were used for Type A situations (e.g., Ik lees/Ik ben aan het lezen 'I am reading') and motion verbs minus endpoint (e.g., Ik fiets/Ik ben aan het fietsen 'I am cycling'). It is assumed that these predicates do not require an (spatial or temporal) adjunct to hold as a reportable event. Predicates describing Type B situations always include a direct object (e.g., Ik brei een sjaal/Ik ben een sjaal aan het breien 'I am knitting a scarf'). Elicitation studies (Flecken 2010) show that speakers who use the aan het-form 
Table 4. Situation types presented in verbal form in the acceptability judgment task

Type A situations
voetballen
pianospelen
biljarten
surfen
lezen
Type B situations, effected object
(een poppetje) tekenen
(een boerderij) schilderen
(een surprise) knutselen
(een sjaal) breien
(een werkstuk) maken
(een boek) schrijven
(een beeld) boetseren
(een vliegtuigje) vouwen
(een kaartenhuis) bouwen
Type B situations, affected object
(rommel) opruimen
(bladeren) vegen
(bomen) omzagen
(interieur) veranderen
(een boterham) opeten
(planken) doorzagen
(een bord) breken
(een pan) afwassen
(een blik) open maken
(een komkommer) snijden

Motion events, minus endpoint wandelen

varen

fietsen

klimmen

zwemmen

Motion events, plus endpoint

(X)(naar Amsterdam) brengen

(naar Frankrijk) rijden

(naar de finish) kruipen

(in het water) springen

(een winkel in) lopen

(X) (naar de auto) dragen

0 -state events 5 items

(een hond) hebben

(het antwoord/de oplossing) weten

van poetsen houden

hopen dat. . .

(in Utrecht) wonen

'to play football'

'to play piano'

'to play billiards'

'to surf'

'to read'

9 items

'to draw a puppet'

'to paint a farm'

'to tinker a surprise'

'to knit a scarf'

'to make an assignment'

'to write a book'

'to mould a statue'

'to fold a paper airplane'

'to build a house of cards'

10 items

'to tidy up a mess'

'to sweep leaves'

'to cut down trees'

'to change the interior'

'to eat up a sandwich'

'to saw logs'

'to break a plate'

'to wash up a pan'

'to open a can'

'to cut a cucumber'

5 items

'to stroll'

'to sail'

'to cycle'

'to climb'

'to swim'

6 items

'to bring X to Amsterdam'

'to drive to France'

'to crawl to the finish line'

'to jump in the water'

'to enter a store'

'to carry X to the car'

'to have a dog'

'to know the answer/solution'

'to love cleaning'

'to hope that X'

'to live in Utrecht'

Total no. of items 
to describe Type B situations (as presented in video clips) have no clear preference when it comes to mentioning the specific object or not (distribution of object mentioned - object not mentioned is about 50/50, and this is similar to the distribution found when the simple form is used). Mention of a direct object in a predicate with aan het is not a syntactic constraint on use of the form and for this reason it was not considered a confounding variable in speakers' judgments of Type B situations.

\section{Results: all data}

\subsection{Overview of total number of choices made per group}

In total, 4704 answer-choices are made by 113 subjects ( 60 male, 53 female). ${ }^{10}$ An overview of data points (42 answer-choices per subject, including two practice items) ${ }^{11}$ is depicted in Table 5 below.

In order to compare the number of choices for the aan het-construction between groups, z-tests for comparing proportions between independent samples are conducted. ${ }^{12}$ No significant difference was found between groups 1 and 2 ( $z=0.78$, n.s.). The comparison between group 1 and group 3 , however, shows a significant difference $(z=3.63, p<0.05)$. Similarly, a significant difference exists between group 2 and $3(\mathrm{z}=4.21, \mathrm{p}<0.05)$. It seems that the older participant group is less likely to choose the aan het-construction across all contexts and variables, compared to the two younger participant groups who group together in their choices for the aan het-construction.

An analysis of the responses to each question type (question with simple form versus question with aan het-form) per temporal context shows that there is a higher number of aan het choices in response to an aan het question in the past tense context only $\left(\chi^{2}(1)=14.08, \mathrm{p}<0.05\right)$ (other contexts: n.s.). Within this context it is thus a less straightforward issue to choose one of the two answer options since speakers are tempted to follow the grammatical form put to them in the question. It reflects the context's status as being "in the middle", so to speak, between the prototypical context for aan het (here-and-now context) and an unlikely context of use (habitual context). Both other contexts show no influence of question type.

Table 5. Overview of all data

\begin{tabular}{lll}
\hline Group $1-14-18$ year-olds & Group 2-20-30 year-olds & Group $3-50+$ year-olds \\
\hline 44 subjects: & 36 subjects: & 33 subjects: \\
19 male, 25 female & 21 male, 15 female & 20 male, 13 female \\
1833 answers chosen $\rightarrow$ & 1510 answers chosen $\rightarrow$ & 1361 answers chosen $\rightarrow$ \\
645 answers $(\mathbf{3 5 \%})=$ aan het & 551 answers $(\mathbf{3 7 \%})=$ aan het & 396 answers $(\mathbf{3 0 \%})=$ aan het \\
\hline
\end{tabular}




\subsection{TT-placement}

When comparing the choices for the aan het-construction versus the simple form within the three temporal contexts, a chi square test gives a significant difference $\left(\chi^{2}(2)=635.50, p<.05\right)$ : Inspection of the standardized residuals show a larger number of choices for aan het when compared to the simple form in the here-and-now context and more choices for the simple form than for aan het in the past tense as well as the habitual context.

When comparing the frequency of choices for the aan het-construction directly between the three contexts, a chi square test shows that aan het is chosen most frequently in the here-and-now context $\left(\chi^{2}(2)=485.73, p<.05\right)$ (see Table 6).

\subsection{Situation types}

Table 7 gives the number of choices for the aan het-construction for the relevant situation types in percentages, across the three age groups.

Table 6. Number of choices for the aan het-construction in the three temporal contexts (across all situation types and age groups)

\begin{tabular}{llll}
\hline & Here-and-now context & Past tense context & Habitual context \\
\hline Choices for aan het & $926(/ 1639=56.5 \%)$ & $441(/ 1567=28.1 \%)$ & $225(/ 1498=15 \%)$ \\
\hline
\end{tabular}

Table 7. Total \% of choices for an het within specific situation types, across all groups and contexts

\begin{tabular}{ll}
\hline Situation type & Proportion of aan het \\
\hline Type A & $49 \%$ \\
(e.g., to play the piano) & $(276 / 565)$ \\
Type B, effected object & $44 \%$ \\
(e.g., to knit a scarf) & $(446 / 1017)$ \\
Type B, affected object & $44 \%$ \\
(e.g., to open a can) & $(496 / 1130)$ \\
Motion verbs - EP & $38 \%$ \\
(e.g., to cycle) & $(217 / 565)$ \\
Motion verbs + EP & $16 \%$ \\
(e.g., to drive to France) & $(109 / 678)$ \\
0-state verbs & $4.1 \%$ \\
(e.g., to know the answer) & $(23 / 565)$ \\
\hline
\end{tabular}


The first comparison focuses on the choices for aan het when dealing with Type A (no inherent qualitative change, e.g., to surf) versus Type B situations (inherent qualitative change of an object, to knit a scarflto saw logs) and no significant difference is found $\left(\chi^{2}(1)=0.551\right.$, n.s.).

In order to measure the effect of an explicit endpoint in the verbal predicate on choices for aan het, a comparison is made between predicates describing motion events plus an endpoint versus those minus an endpoint A chi square test shows that the number of choices for the aan het-construction in the "minus endpoint" condition is greater than the number of choices in the condition "plus endpoint" $\left(\chi^{2}(1)=79.04, p<0.05\right)$. A further comparison also includes a differentiation between motion events plus an endpoint described as having a long trajectory (longer duration) and those described as having a short trajectory (shorter duration), in order to test for the factor duration in this context. A chi-square test shows a significantly higher number of choices for the aan het-construction in the group of motion events plus endpoint given a long trajectory (duration) and less choices for aan het in the short duration condition $\left(\chi^{2}(1)=3.11, \mathrm{p}<.05\right)$.

\section{Results: Comparison between age groups}

\subsection{TT-Placement}

The proportion of choices for the aan het-construction for situations in the here-and-now context differs significantly between the 14-18 year-olds (group $1)$ and the $50+$ year-olds (group 3) $(z=2.51, p<0.05)$ and the 20-30 year olds (group 2) and the eldest participant group $(\mathrm{z}=3.92, \mathrm{p}<0.05)$ (see Figure $8)$.

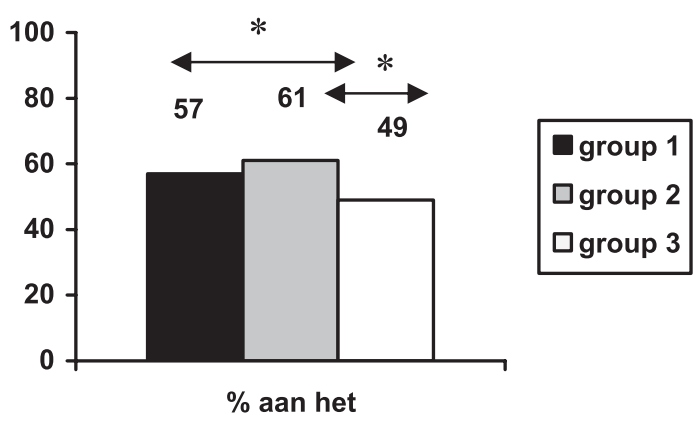

Figure 8. Choices for aan het - here-and-now context $^{13}$ 
The older participants' proportion of choices for aan het is significantly below the proportion of choices of the younger speaker groups in the here-andnow context.

Turning now to the past tense context: again the 14-18 year-olds and the 20-30 year-olds do not differ in their choices for the aan het-construction $(\mathrm{z}=0.10$, n.s.). As with the here-and-now context, the results also show that both group 1 and 2 differ significantly from the 50+ year-old group (group $1 \mathrm{vs.}$ group 3: $\mathrm{z}=3.38, \mathrm{p}<0.05$, group 2 vs. group $3: \mathrm{z}=3.16, \mathrm{p}<0.05$ ), since they tend to choose the aan het-construction a greater number of times (Figure 9).

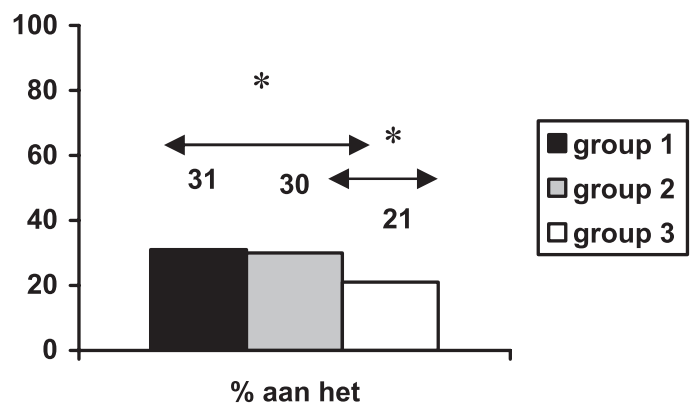

Figure 9. Choices for aan het - past tense context

The habitual context reveals a rather different picture: The three groups do not differ in the number of choices for the aan het-construction (group $1 \mathrm{vs.}$ group 2: $\mathrm{z}=0.22$, n.s., group 1 vs. group $3: \mathrm{z}=1.04$, n.s., group 2 vs. group 3: $\mathrm{z}=0.79$, n.s.) (Figure 10).

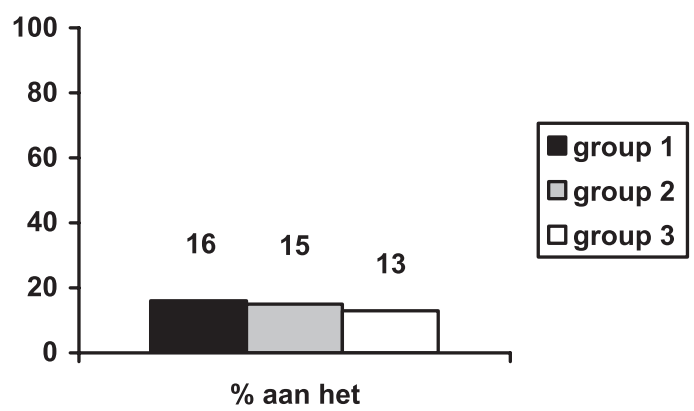

Figure 10. Choices for aan het - habitual context 


\subsection{Situation types}

For Type A situations there are no significant differences between the three groups: Participants of all ages choose the aan het-construction a similar amount of times (see Figure 13).

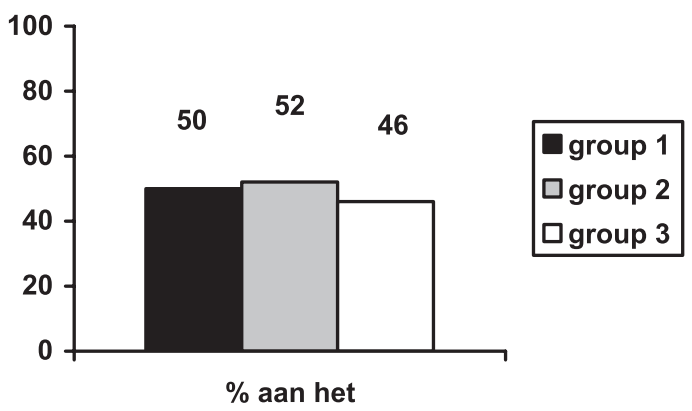

Figure 11. Choices for an het - Type A situations

For Type B situations with an effected object group 1 chooses the aan hetconstruction more often than group $3(\mathrm{z}=1.72, \mathrm{p}<0.05)$, but there is no difference between group 1 and $2(z=0.95$, n.s.), nor between group 2 and 3 $(\mathrm{z}=0.77$, n.s.) (Figure 12).

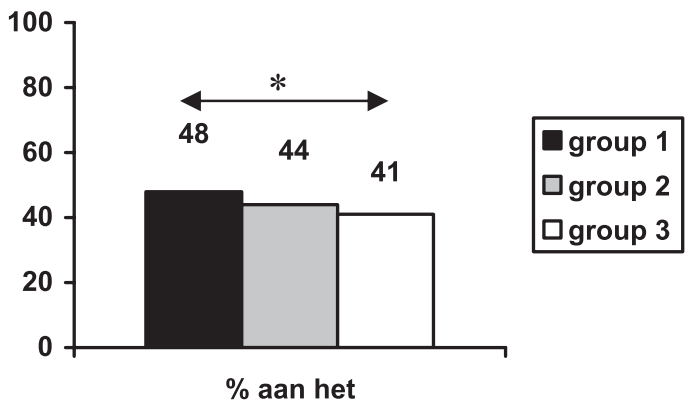

Figure 12. Choices for aan het - Type B situations, effected object

Within the group of Type B situations with an affected object, the proportion of choices for aan het is slightly higher in group 2 than in group 1, but this is 
merely a trend $(\mathrm{z}=1.55, \mathrm{n} . \mathrm{s}$.). There is a significant difference between group 2 and $3(\mathrm{z}=2.09, \mathrm{p}<0.05)$ (Figure 13).

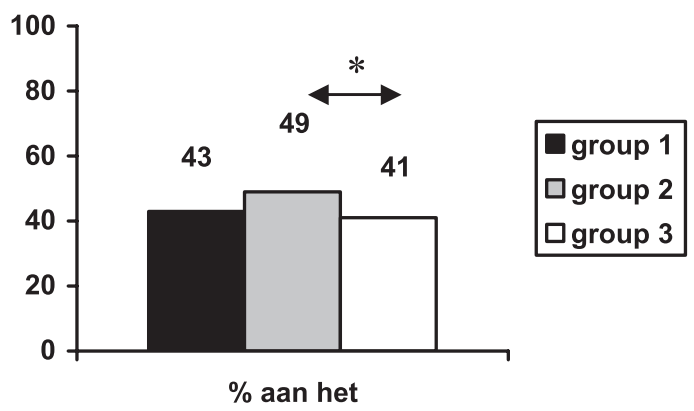

Figure 13. Choices for aan het - Type B situations, affected object

The motion event items minus an endpoint do not show significant differences in the choices made for aan het across the groups (Figure 14).

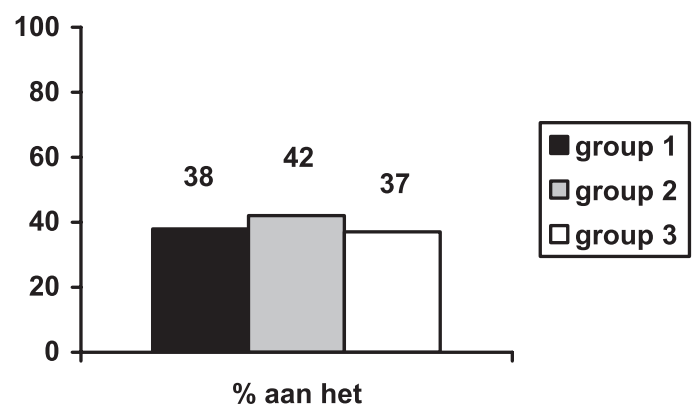

Figure 14. Choices for aan het - motion events minus endpoint

There are differences between all age groups for motion events plus a mentioned endpoint (Group 1 vs. group 2: $\mathrm{z}=1.92, \mathrm{p}<0.05$, group 1 vs. group 3: $\mathrm{z}=6.03, \mathrm{p}<0.05$, group 2 vs. group $3: \mathrm{z}=4.51, \mathrm{p}<0.05$ ). The results are clearly graded along the variable age: The youngest participants are the most tolerant in choosing the aan het-construction in this context, whereas the eldest participants are the most conservative (Figure 15).

Looking at the group of 0 -state verbs, we see that the oldest participant group is most conservative when judging use of the aan het-construction, and the results differ significantly from both younger groups (group 1 vs. group 3: $\mathrm{z}=2.47, \mathrm{p}<0.05$, group 2 vs. group $3: \mathrm{z}=2.75, \mathrm{p}<0.05$ ) (Figure 16). 


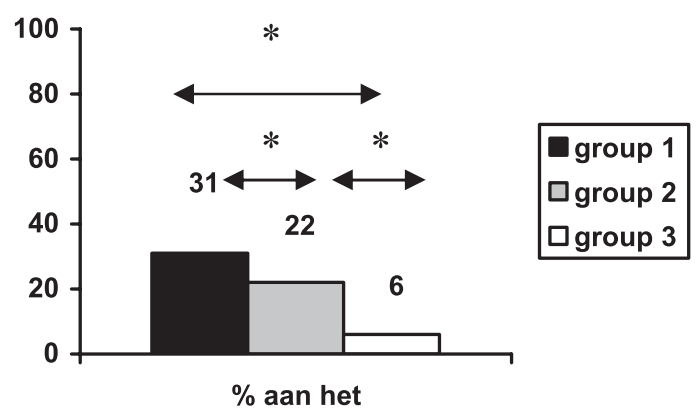

Figure 15. Choices for aan het - motion events plus endpoint

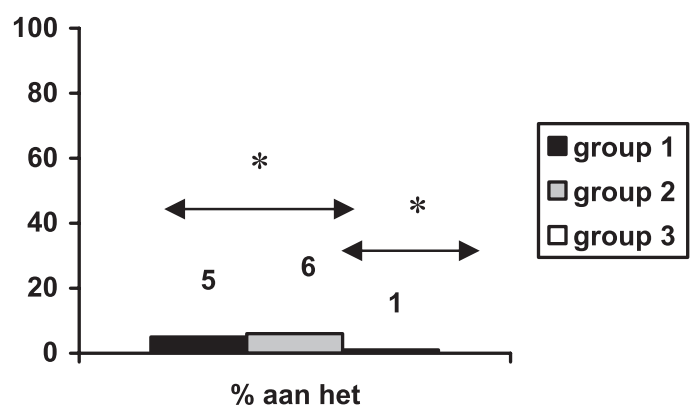

Figure 16. Choices for aan het - 0-state verbs

\section{Discussion and conclusions}

\subsection{Validity of the method}

Acceptability judgments were used as a tool in order to further investigate trends observed in elicitation studies with regard to the use of the aan hetconstruction in Dutch. The judgment tasks serve in gaining insight into speakers' linguistic representations at the level of overt linguistic knowledge in a domain in which language change is underway, and use of progressive aspect, as expressed by the aan het-construction, is not obligatory in Dutch in any context. The method of investigation is based on a range of language production studies as well as corpus studies and incorporates specific temporal and spatial features which were shown to enhance or constrain use of progressive aspect in production tasks. The incorporation of features tested in this way is relevant in supporting the validity of the method used in the judgment task. 
Acceptability judgment tasks (usually termed "grammaticality judgment tasks") are a well-established tool in the field of language acquisition, for example, where speakers are tested with regard to grammatical competence. In second language acquisition, metalinguistic competence may, however, outstrip actual language use (see discussions in Mandell 1999; Sorace 2003). Since learner languages are typically in a state of flux, the competence of an L2 learner varies at different stages of acquisition, compared to that of a native speaker, where acquisition can be viewed as completed. With respect to explicit tests of the validity of native speakers' as well as learners' acceptability judgments, comparisons to production studies and other methods such as multiple testing have shown that judgments are a reliable tool in assessing behavioural patterns (see Leow 1996; Mandell 1999).

The present study of native speakers' judgments focuses on an area in which the system is in a state of flux with respect to frequency of use of the aan hetconstruction. It set out to investigate the extent to which acceptability judgments overlap with attested trends in language use, given the fact that the aan het-construction, unlike the progressive in English, is not fully grammaticalized. In other words, it is not obligatory in any context of use. The inclusion of speakers covering different age groups allows the comparison of possible age differences with respect to acceptability across specific contexts of use, since age-related differences, where significant correlations can be identified, may shed light on the road of the aan het-construction toward grammaticalization. Observations of this kind can in turn be corroborated with further language production tasks taking the relevant age groups into account.

5.1.1. Comparison to data showing language use. The findings of the judgment tasks are shown to follow the trends found in elicitation studies in that they reflect preferences for and constraints on the use of this aspectual construction on a systematic basis. As in the elicitation studies, specific temporal features, which were hypothesized as relevant for the acceptability of the progressive construction, were implemented in the judgment tasks. The relevant features were identified in a series of crosslinguistic studies on the use of progressive aspect in event construal by native speakers of Italian, French, and Dutch. As mentioned above, the temporal features at issue occur in situations which are typically classified as "activities" in the sense of Vendler (1957), since this is the context in which aspectual distinctions may typically occur (Comrie 1976). In the framework of analysis used in the elicitation tasks, "activities" were differentiated with respect to their core temporal properties (see Carroll et al. 2008; Natale 2009; von Stutterheim et al. 2009). "Activities" such as knitting or baking, for example, were differentiated from singing, or swimming in that baking and knitting show a sequence of sub-events with "changes in state" that lead progressively to the existence of an "effected object" (a 
knitted scarf as the resultant state, for example). With swimming or singing, by contrast, the final state involves no more than the cessation of the activity, with no "change in state" in the case of the participant. There is no tangible result, in contrast to that given with an effected object. In the elicitation tasks, change in state situations leading progressively to a resultant state show the highest occurrence of an aspectual perspective in languages in which use is not yet obligatory in any context; the periphrastic stare + gerund in Italian; en train de in French, and the aan het-construction in Dutch (Carroll et al. 2008). "Change in place" situations, by contrast, which involve directed motion on the part of a vehicle or person, show the lowest rate of occurrence in all these languages (see von Stutterheim et al. 2009; Natale 2009)

In order to trace possible paths toward grammaticalization, the crosslinguistic comparison was extended to Norwegian, since use of means to express an aspectual distinction is relatively low in Norwegian, compared to Dutch and Italian (see Flecken 2010). Given the same elicitation tasks, the findings reveal clear preferences for speakers of Norwegian which are relevant to the present study. The critical situation type in a language in which use of aspect is comparatively low involves situations showing "no change in state". If speakers of Norwegian decide to select an aspectual perspective, contexts where the situation shows an event that is simply "ongoing", with no change in state or progressive component, constitute the preferred situation of use. By contrast, the aan het-construction in Dutch shows a high sensitivity to situations with a progressive component, while situations with "no change in state" are close behind.

The acceptability judgments in the present paper reveal a similar pattern for Dutch since the attractor effect for "change in state" situations and situations with "no change in state" are equal. ${ }^{14}$ These findings are significant since both studies, the elicitation task and the acceptability judgment task, show that the aan het-construction in Dutch is sensitive to situations with a progressive component.

With regard to the question of potential age-related differences across situation types, there are relevant findings across the age groups. While there are no significant differences with regard to acceptability between the three groups for situations showing "no change in state", since this situation type is equally acceptable for all three age groups, there are differences for change in state situations. Overall significant differences were observed between speakers who are under versus over 50: For situations with a change in state and an effected object, the 14-18 year olds choose the aan het-construction more often than the group over 50 . There is no difference in this context between the 14-18 year olds and the $20-30$ year olds, nor between $20-30$ year olds and the $50+$ group. The main divergence occurs for the $14-18$ and the 50+ group. All groups, on the other hand, show evidence of the presence of similar constraints 
for motion events where both acceptability, as well as use, is rated as extremely low. Older speakers seem less likely to view the aan het construction as acceptable in contexts which are most dynamic for younger speakers in both elicitation as well as judgment tasks. Situations showing no change in state have the edge with regard to acceptability for the older age group. In this sense the present task reveals a trace of what may be the path of the aan het-construction on the road to grammaticalization in Dutch - from preferences for use in situations with no-change in state to those involving a clear progressive component.

The findings indicate that the selection of temporal concepts during conceptualization in language production is a process that involves both bottom-up (stimulus driven, i.e., driven by the temporal features presented in the situation types in the stimuli) as well as top-down knowledge-driven processing these two sources of linguistic knowledge seem to also be activated, to a certain degree at least, when making acceptability judgments.

\section{Summary and conclusions}

The analysis of speakers' judgments of the aan het-construction with respect to the selected set of the variables - "here-and-now", Topic Time contrast, situation types and duration - showed significant results. First of all, choices for the aan het-construction in the three different temporal contexts revealed that Topic Times that are anchored in the here-and-now represent the main temporal variable when anchoring the Dutch progressive. The expression of ongoingness in the here-and-now may constitute a core function of a developing progressive marker: The aan het-construction is chosen in $56 \%$ of all cases. By contrast, situations where the Topic Time (TT) refers to multiple or recurrent Situation Times (habitual situations) were judged as the least suitable type of TT-placement for use of the aan het-construction. The expression of habitual meaning is not judged as possible with the Dutch progressive form. As in English, the Dutch progressive conforms with the requirement of a limitation on the Time of Situation and requires a predicate that allows for TT-contrasts. Although selection of the aan het-construction within the past tense context is relatively frequent (the aan het-construction was chosen in $28 \%$ of all cases), showing that preferences can extend beyond the posited prototypical attractorvariable for progressives, i.e., an event anchored in the here-and-now, the context's relatively instable status as a suitable environment for aan het is demonstrated by the fact that there was an effect of question type on the type of answer chosen (more responses with the aan het-form in reply to aan het questions).

With respect to situation types, that is, situations showing a qualitative change of an entity (Type B: someone moulding a vase), compared to those 
that do not (Type A: someone swimming), the findings for acceptability judgments of the aan het-construction indicate no preference in choosing the form more frequently when dealing with Type A rather than Type B situations. Section 5.1.1 above discusses these findings and compares them to elicitation data.

Overall, a marked decrease can be observed in choices for aan het with motion events minus endpoint, on the one hand, and motion events plus endpoint and 0 -state verbs on the other hand. The latter two situation types constitute a clear constraint on choices for the Dutch progressive. Looking more closely at motion events, there is a marked decrease in choices for aan het with judgments for motion event descriptions that involve motion toward an endpoint, as opposed to those without an endpoint, as was also observed in speech production studies (see 1.2). Interestingly, for the identification of relevant variables, selection of the aan het construction with motion events that include an explicit endpoint is more likely to occur if the trajectory extends in space and thus has duration. This underlines the role of this variable for developing markers of progressive aspect. The findings for motion events tie in with speech production studies that focus on the use of forms expressing ongoingness when describing different situation types. In overall terms, motion events with an explicit endpoint show a low attractor effect in the use of forms expressing ongoingness in Dutch, Italian and French (Carroll et al. 2008), Norwegian and German (Flecken 2010).

The comparisons between speakers of different age groups show that for the older participants there are clearer restrictions on the contexts where use of the aan het-construction is considered appropriate compared to the two younger groups. For the older participants, the aan het-construction does not relate to any kind of situation that is anchored in the here-and-now: the aan hetconstruction is judged most appropriate when the means of expression used represent an "activity" (a Type A situation). This finding indicates that the variable "age" may be a relevant factor in an evolving system, for situation types showing the variable "progression" at least.

All in all, the current study has sketched the range of application and preferred contexts of selection of the aan het-construction in Dutch by specifying the relevant selectional restrictions found for the different age groups studied. The results show that the younger speakers in the sample were (in some cases) less constrained by specific temporal variables manipulated within the task, compared to the older speakers (i.e., duration of the interval at issue, events in progression with an inherent qualititative change or those without a qualitative change, the here-and-now anchor (present vs. past) and TT-contrast-potential). It has also been shown that acceptability judgments tap into processes related to language production to a large degree, since the current results converge in most respects with event elicitation studies. The findings bring into focus 
the set of variables underlying the meaning and the function of the aan hetconstruction in Dutch.

Finally, the data have supported a scale of grammaticalization that shows the relevance of specific situational features on selection of progressive aspectual constructions. The acceptability judgment data indicate that the Dutch aan hetconstruction has entered a stage of development in which selection goes beyond the prototypical usage context, which is represented by ongoing "activities" with long duration in the here and now. The construction is also considered appropriate in past tense contexts, and with situations involving a qualitative change of an entity. In this sense, progressive aspect Dutch seems to be at a similar stage of development as the relevant construction in Italian, but differs from the highly grammaticalized progressive aspectual marker in English.

Received 8 September 2008

Revised version received 31 May 2010

University of Heidelberg

\section{Appendix. Acceptability judgment task (Version 1a of 6 versions)}

V1a, Subnr: $\quad$ M/V !!! Leeftijd 'Age': . . !!!

Kies het beste antwoord uit (door de letter a) of b) te omcirkelen) en geef aan hoe acceptabel je DE ANDERE OPTIE vindt (dus de optie die je niet gekozen hebt), op een schaal van 1 tot $5^{*}$, door ook het geschikte cijfer te omcirkelen.

Bedankt!

* 1 = onacceptabel

2 =een beetje onacceptabel

3 = onacceptabel, noch acceptabel

4 = beetje acceptabel

$5=$ acceptabel

'Choose the best answer (by circling letter a or b). Also indicate how acceptable you find THE OTHER OPTION (so the option you did not choose), on a scale from 1 to $5^{*}$, by also circling the appropriate number.

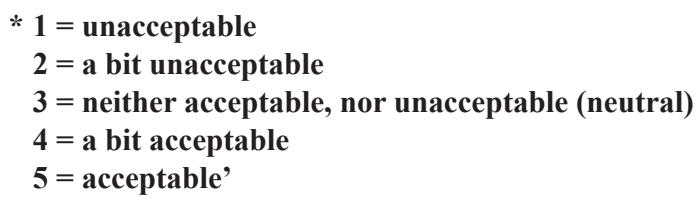

\section{OEFENITEMS (de experiment-leider geeft je feedback)}

'Practice items (the experimenter will give feedback)'

a) Stel: Je woning is een enorme bende, en vandaag besluit je er echt iets aan te gaan doen. Je haalt de stofzuiger en de dweil tevoorschijn en gaat aan de slag. Op een 
gegeven moment gaat je telefoon. Iemand vraagt: "Wat ben je nu aan het doen?". Je antwoordt:

a) Ik poets

b) Ik ben aan het poetsen

\section{1-2-3-4-5}

'Imagine: Your apartment is a mess and today you decide to do something about it. You bring out the hoover and a mop and you start working. At a given time, your phone rings. Somebody asks: "What are you doing right now?". You answer:

a) I clean

b) I am at-the-clean'

b) Stel: Je hebt vorige maand een spannende film gekeken. Er vond een enorme explosie plaats, dus dat lawaai galmde een hele tijd door de huiskamer. Nu kom je een huisgenoot tegen die vraagt: "Hee, wat deed jij vorige maand toch?". Je vertelt:

a) Er explodeerde een vliegtuig in de film

b) Er was een vliegtuig aan het exploderen in de film

\section{1-2-3-4-5}

'Imagine: Last month you watched a very exciting film. There was an enormous explosion, which produced an awful lot of noise throughout the house. Now you run into a housemate who asks: "What did you do last month?". You tell him/her:

a) There exploded an airplane in the film

b) There was an airplane at-the-explode in the film'

\section{- HEB JE NOG VRAGEN? -}

'Any questions?'

\section{TEST ITEMS}

1) Stel: Op een herfstachtige dag loop je even lekker door het bos. Na een tijdje lopen gaat je telefoon en iemand vraagt: "Wat ben je nu aan het doen?". Je zegt:

c) Ik wandel

d) Ik ben aan het wandelen

1-2-3-4-5

'1) Imagine: On a rainy day, you are walking through the forest. After a while, your phone rings and somebody asks you: "What are you doing right now?". You answer:

a) I walk

b) I am at-the-walk'

2) Stel: Je werkt bij een timmerbedrijf en bent verantwoordelijk voor het maken van kozijnen. Hier ben je dus elke dag mee bezig. Op een dag belt een oude bekende en hij vraagt naar je baan: "Wat ben je tegenwoordig aan het doen?". Je antwoordt:

a) Ik ben planken aan het doorzagen

b) Ik zaag planken door

\section{1-2-3-4-5}

'Imagine: You are employed at a carpenter's and you are responsible for the construction of window frames. This is what you do every day. One day, an old friend calls and asks you about your job: "What are you doing nowadays?". You answer: 
a) I am logs at-the-saw

b) I saw logs'

3) Stel: Je werkt bij een postorderbedrijf. Tijdens een lange rit op de snelweg om een pakket af te leveren word je gebeld door een bekende die vraagt: "Wat ben je nu aan het doen?". Je antwoordt:

a) Ik ben een pakket naar Amsterdam aan het brengen

b) Ik breng een pakket naar Amsterdam

$1-2-3-4-5$

'Imagine: You work for a mail order service. During a long trip on the motorway to deliver packages, you receive a phonecall of a friend who asks: "What are you doing right now?" You answer:

a) I am a package to Amsterdam at-the-bring

b) I bring a package to Amsterdam'

4) Stel: Het is deze zomer heel mooi weer en samen met een groep vrienden besluiten jullie om voortaan elke dag buiten iets sportiefs te gaan ondernemen. Samen met een vriend fiets je elke middag naar een veld bij jullie in de buurt om een potje voetbal te gaan spelen. Je vader vraagt telkens als je weggaat: "Wat doe je toch steeds 's middags?". Je zegt:

a) Ik ben aan het voetballen

b) Ik voetbal

$1-2-3-4-5$

'Imagine: This summer the weather is lovely and together with a group of friends you decide to do something sporty outdoors each day. Every afternoon you cycle to a lawn nearby, to play a game of football. Everytime you leave your father asks you: "What do you do every afternoon?" You say:

a) I am at-the-football play

b) I play football'

5) Stel: Je liep vorige week met de Vierdaagse mee. Je loopt nu dus een beetje mank en je voeten zijn echt kapot. Iemand vraagt je wat er met je aan de hand is en of het zwaar voor je was. Je trekt een zuur gezicht en vertelt dat het echt een marteling was. Hij|zij vraagt dus: "Hoezo? Wat deed je vorige week dan?". Je vertelt:

a) Ik was elke dag bijna naar de finish aan het kruipen

b) Ik kroop elke dag bijna naar de finish/Ik ben elke dag bijna naar de finish gekropen $1-2-3-4-5$

'Imagine: Last week you joined the Four days' marches. Now, your muscles are sore and your feet are hurt. Somebody asks you what is the matter and whether last week's event was difficult for you. You look disturbed and you tell the other person that it was a true torture. He/she asks: "Why? What did you do last week?". You tell him/her:

a) I was each day almost to the finishline at-the-crawl

b) I almost crawled to the finishline each day'

6) Stel: Het is bijna Sinterklaas en je hebt net een kadootje gekocht voor degene wiens lootje je hebt getrokken. Nu moet je nog beginnen aan een surprise. Je haalt de eierdozen en de melkpakken tevoorschijn die je verzameld hebt en gaat ijverig aan de slag. 
Ondertussen gaat je telefoon. "Wat doe je nu?" vraagt de persoon aan de andere kant van de lijn. Je antwoordt:

a) Ik knutsel een surprise voor Sinterklaas

b) Ik ben een surprise aan het knutselen voor Sinterklaas

$1-2-3-4-5$

'Imagine: It is almost Sinterklaas and you have just bought a present for the person whose lot you drew. You start working on the surprise-wrapping. You bring out the milk cartons that you collected and you start working industriously. Meanwhile, the phone rings. "What do you do now?" the person at the other end asks. You answer:

a) I tinker a surprise for Sinterklaas

b) I am a surprise at-the-tinker for Sinterklaas'

7) Stel: Je zit nu in de klas, en de lerares vraagt of iemand iets van honden weet. Uitvoerig begin je je buurvrouw over je hond te vertellen. De lerares komt niet meer boven het lawaai uit, en vraagt je dus: "Hee, wat ben jij nu aan het doen?" Je probeert haar duidelijk te maken dat het erg belangrijk is wat je te vertellen hebt:

a) Ja maar, ik ben een hond aan het hebben!

b) Ja maar, ik heb een hond!

$1-2-3-4-5$

'Imagine: You are in class right now and the teacher asks if anyone has any knowledge about dogs. You start an elaborate conversation with your neighbour about your dog. The teacher is bothered by the noise and asks: "What are you doing now?" You try to explain to her that you have important things to say:

a) Yes, but I am a dog at-the-have!

b) Yes, but I have a dog!'

8) Stel: Vorige maand was je een weekje op vakantie in Frankrijk. Vandaag is het precies een maand geleden dat je naar Frankrijk bent gereden. Je bent met iemand aan de telefoon en deze persoon vraagt: "Wat deed je vorige maand?" Je zegt:

c) Ik reed naar Frankrijk/Ik ben naar Frankrijk gereden

d) Ik was naar Frankrijk aan het rijden

\section{$1-2-3-4-5$}

'Imagine: Last month you were on a holiday in France. Exactly a month ago today, you were driving to France. You are talking on the phone and the person on the other end asks: "What did you do last month?". You say:

a) I drove to France

b) I was to France at-the-drive'

9) Stel: Je bent twee maanden geleden aangenomen bij een software bedrijf. Je taak is het herstructureren van de boekhouding. Helaas was je voorganger niet zo zorgvuldig, dus de komende tijd is je taak het opruimen van de rommel van je voorganger. Vandaag, terwijl je druk bezig bent, klopt een collega aan en hij vraagt: "Wat ben je nu aan het doen?" Jij vertelt:

a) Ik ben de rommel van mijn voorganger aan het opruimen

b) Ik ruim de rommel van mijn voorganger op

$1-2-3-4-5$ 
'Imagine: Two months ago you were hired at a software company. It is your job to restructure the company's bookkeeping. Unfortunately, your predecessor was sloppy, so your main job in the time ahead is to clean up your predecessor's mess. Today, while you are busy working, a colleague drops by and asks: "What are you doing right now?" You tell him:

a) I am the mess of my predecessor at-the-tidy up

b) I tidy up the mess of my predecessor'

10) Stel: Je bent vandaag met vrienden in een zwembad. Je staat op de rand van het bad, klaar om te springen, terwijl een vriend net onder die rand doorzwemt. Hij kijkt omhoog en vraagt: "Wat doe je nu?" Terwijl je je afzet, roep je:

c) Kijk uit! Ik spring in het water!

d) Kijk uit! Ik ben in het water aan het springen!

'Imagine: You are in a pool with friends. You are standing on the edge of the pool, ready to jump, while a friend is swimming right beneath you. He looks up and asks: "What do you do now?". As you jump, you shout:

a) Watch out! I jump in the water

b) Watch out! I am in the water at-the-jump'

11) Vorig jaar was je met een vriend(in) op vakantie, een weekje uitrusten op het strand. Je hebt eigenlijk vooral gelezen en geslapen . . Nu vraagt een collega je: "Wat deed je vorig jaar op vakantie?"

a) Ik las/Ik heb gelezen

b) Ik was aan het lezen

\section{$1-2-3-4-5$}

'Imagine: Last year you were on holidays with a friend; a weak of relaxation on the beach. Your main activities were reading and sleeping. Now a colleague asks: "What did you do on holidays last year?"

a) I read

b) I was at-the-read'

12) Stel: Vorig jaar in de zomervakantie was het prachtig weer in Nederland. Je was met vrienden een paar dagen op een zeilboot in Zeeland. Je moeder vraagt nu naar je vakantieplannen voor dit jaar. Je vertelt haar dat, als het goed weer is, je hetzelfde wilt doen als vorig jaar. Ze vraagt: "Wat deed je vorig jaar dan?" Je vertelt haar:

a) Ik was aan het varen

b) Ik voer/Ik heb gevaren

$1-2-3-4-5$

'Imagine: Last year during the summer holidays the weather in Holland was wonderful. You were on a sailing boat in Zeeland for a few days, with a group of friends. Your mother is now asking about your plans for this year's holidays. You tell her that, providing the weather is good, you would like to do the same as last year. She asks: "What did you do last year?" You tell her:

a) I was at-the-sail

b) I sailed' 
13) Stel: Je wilt boodschappen gaan doen. Je staat op het punt de winkel in te lopen, maar je ziet dat iemand de winkel inloopt en dat er ondertussen een bord naar beneden op z'n hoofd valt. Je schrikt je kapot, want dat is jou ook al een keer gebeurd! Je vertelt iemand dat je vorige maand ook een bord op je hoofd hebt gekregen. Hij/zij vraagt: "Wat was je vorige maand dan aan het doen?"

a) Ik was vorige maand ook deze winkel in aan het lopen!

b) Ik liep vorige maand ook deze winkel in!|Ik ben vorige maand ook deze winkel in gelopen!

\section{1-2-3-4-5}

'Imagine: You want to do the grocery shopping. You are about to enter the store, but you notice that while someone who is walking into the store, a sign falls down on his head. You are shocked, because the same thing happened to you once also! You tell someone that last month, also a sign fell on your head. He/she asks: "What were you doing last month?"

a) I was lost month also this stop at-the-enter!

b) Last month I also entered this shop!'

14) Stel: Je bent bezig met de afwas, maar er glipt iets uit je handen. Je probeert het nog op te vangen, maar het is te laat. Ondertussen heeft je vriend(in) je gestuntel opgemerkt en hij/zij vraagt: "Wat doe je nu?". Je zegt:

c) Ik breek een bord

d) Ik ben een bord aan het breken

'Imagine: You are busy doing the dishes but suddenly something slips through your hands. You try to catch it, but it is too late. Meanwhile your friend has noticed what is going on and asks: "What do you do right now?"

a) I break a plate

b) I am a plate at-the-break'

15) Stel: Je bent schrijver/schrijfster van beroep en je huidige meerjarige project is het schrijven van een autobiografie. Nu ben je op een reünie van je oude middelbare school. Je komt een oude vriend(in) tegen die vraagt naar je beroep: "Wat doe je tegenwoordig?'. Je antwoordt:

a) Ik ben een boek aan het schrijven

b) Ik schrijf een boek

\section{1-2-3-4-5}

'Imagine: You are a professional author and your contemporary long-term project is to write an autobiography. Today you are at a reunion of your old secondary school. You run in to an old friend who asks about your profession: "What do you do nowadays?". You answer:

a) I am a book at-the-write

b) I write a book'

16) Stel: Het is vandaag lekker weer en je fietst even een stukje over de dijk. Tijdens het fietsen gaat je telefoon en de persoon aan de andere kant van de lijn vraagt: "Wat ben jij nu aan het doen?" 
c) Ik ben aan het fietsen

d) Ik fiets

\section{$1-2-3-4-5$}

'Imagine: Today, the weather is nice and you are cycling along the dyke. While cycling, your phone rings and the person at the other end asks: "What are you doing right now?"

a) I am at-the-cycle

b) I cycle'

17) Stel: Je vertelt een vriendin een grappig verhaal over wat je vorige maand hebt meegemaakt. Een vriend van je klungelde enorm met het repareren van zijn fiets, maar hij was te koppig om je om hulp te vragen. Je begint spontaan weer te lachen, dus je vriendin wordt nieuwsgierig en ze vraagt: "Waarom lach je? Wat deed jij vorige maand?". Lachend vertel je haar:

a) Ik wist hoe het moest!

b) Ik was aan het weten hoe het moest!

$1-2-3-4-5$

'Imagine: You are telling a friend a funny story about something you experienced last month. A friend of yours was having problems repairing his bike, but he was too stubborn to ask for your help. Spontaneously, you start laughing again, so your friend gets curious and asks: "Why are you laughing? What did you do last month?" You tell her:

a) I knew how to do it!

b) I was at-the-know how to do it!'

18) Stel: Je bent vandaag thuis en je speelt een tijdje met het zoontje van een vriend. Hij haalt een pak kaarten tevoorschijn en begint ze een voor een op elkaar te stapelen. Op een gegeven moment gaat je telefoon. Iemand vraagt: "Wat ben je nu aan het doen?" Je antwoordt:

a) Ik bouw een kaartenhuis

b) Ik ben een kaartenhuis aan het bouwen

\section{1-2-3-4-5}

'Imagine: You are at home playing with your friend's child for a while. He brings out a deck of cards and starts stacking them one on top of the other. At a given time, your phone rings. Somebody asks: "What are you doing right now?" You answer:

a) I build a card house

b) I am a card house at-the-build'

19) Stel: Je bent een professionele biljarter. Iemand wil weten wat je beroep is en hij vraagt: "Wat doe je in het dagelijks leven?" Je vertelt hem:

a) Ik ben aan het biljarten

b) Ik biljart

1-2-3-4-5

'Imagine: You are a professional billiards player. Somebody would like to know what you do for a living and he asks: "What do you do in daily life?" You tell him:

a) I am at-the-billiards play

b) I play billiards' 


\section{M. Flecken}

20) Stel: Je werkt bij de gemeente in de plantsoenendienst. Jullie moeten elke week wel ergens een boom omzagen. Je wordt op een dag opgebeld door een oude bekende die vraagt: "Wat ben jij aan het doen tegenwoordig?" Je vertelt hem/haar:

a) Ik zaag bomen om

b) Ik ben bomen aan het omzagen

\section{$1-2-3-4-5$}

'Imagine: You work at parkkeeping. Every week it is your job to cut down trees somewhere. One day an old friend calls and asks: "What are you doing nowadays?" You tell him/her:

a) I cut down trees

b) I am trees at-the-cut down'

21) Stel: Vorig jaar in de herfst werkte je bij een tuiniersbedrijf. Vooral in oktober was het vies weer en jullie moesten kilo's bladeren opruimen in alle parken in de stad. Je vriend(in) vraagt: "Wat deed je vorig jaar oktober?". Je vertelt:

a) Ik veegde bladeren/Ik heb bladeren geveegd

b) Ik was bladeren aan het vegen

\section{$1-2-3-4-5$}

'Imagine: Last year in the fall you worked for a gardening company. In October, the weather was bad and you had to clean up kilos of leaves in all the parks throughout town. A friend asks: "What did you do last october?" You tell him:

a) I swept leaves

b) I was leaves at-the-sweep'

22) Stel: Omdat je broer op vakantie is, ga je vandaag zijn huis even flink onder handen nemen. Gewapend met een stofzuiger, een emmer en een dweil ga je aan het werk. Als je net met de keuken bent begonnen, belt de buurman aan. Hij vraagt: "Wat doe jij nu? Je lijkt wel gek!' Je zegt:

a) Oh, nee hoor. Ik ben van poetsen aan het houden

b) Oh, nee hoor. Ik hou van poetsen

$1-2-3-4-5$

'Imagine: Because your brother is on holidays, you decide to work on his appartment today. You start working with a hoover, a bucket and a mop. After you just started working on the kitchen, the neighbour rings the doorbell. He asks: "What do you do now? You must be mad!" You say:

a) Oh no, I am cleaning at-the-love

b) Oh no, I love cleaning'

23) Stel: Elk jaar in de winter brei je een mooie sjaal voor je opa. Dit is iets waar je je elke zondag mee bezighoudt, vooral als het regent. Een vriend(in) vraagt je: "Wat doe je elke winter?".

c) Ik brei een sjaal

d) Ik ben een sjaal aan het breien

\section{$1-2-3-4-5$}

'Imagine: Every year in winter you knit a nice scarf for your grandfather. You work on the scarf each Sunday, especially when it rains. A friend asks: "What do you do each winter?" 
a) I knit a scarf

b) I am a scarf at-the-knit'

24) Stel: Vandaag wil je in de buitenlucht een schilderij maken. Je rijdt naar een dorp in de buurt en ziet een mooie boerderij. Je gaat ergens zitten, neemt het beeld in je op en haalt het doek en je kwasten tevoorschijn. Na een tijdje belt een vriend je op: "Wat ben je nu aan het doen?" vraagt hij. Je vertelt hem:

a) Ik schilder een boerderij

b) Ik ben een boerderij aan het schilderen

$1-2-3-4-5$

'Imagine: Today you feel like making a painting somewhere outside. You drive to a village in the area and you spot a lovely farm. You decide to sit down, take in the image, and take out the canvas and the brushes. After a while a friend calls and asks: "What are you doing right now?" You tell him:

a) I paint a farm

b) I am a farm at-the-paint'

25) Stel: Je bent aan het oefenen op de piano. Het klinkt best aardig en je gaat er al een tijdje helemaal in op. Op een gegeven moment gaat de telefoon. Een vriend vraagt:

"Wat ben je nu aan het doen?". Je antwoordt:

c) Ik speel piano

d) Ik ben piano aan het spelen

\section{$1-2-3-4-5$}

'Imagine: Today you have to practice for a piano performance. It sounds quite nice and you are totally absorbed in it. At a given time the phone rings. A friend asks: "What are you doing right now?"

a) I play the piano

b) I am piano at-the-play'

26) Stel: Deze zomer wil je wat geld bijverdienen, dus je werkt bij een verhuisbedrijf. Jouw taak is het inladen van de verhuiswagen. Helemaal niet zo spannend dus, en ook nog erg zwaar werk: Elke dag til je zware meubels en dozen. Op een dag belt een studievriend je en hij vraagt: "Wat ben je aan het doen deze zomer?". Je vertelt diegene:

a) Ik draag loodzware dozen naar een verhuiswagen

b) Ik ben loodzware dozen naar een verhuiswagen aan het dragen.

$1-2-3-4-5$

'Imagine: This summer you would like to earn some extra money, so you work for a removal firm. It is your job to load the trucks. This is not very exiting and also strenuous: Every day you have to carry heavy furniture and boxes. One day a friend from university calls and he asks: "What are you doing this summer?" You tell him/her:

a) I carry heavy boxes to the truck

b) I am heavy boxes to the truck at-the-carry'

27) Stel: Vorige zomer was je in Canada in de bergen om te klimmen. Het was een prachtige ervaring, alleen elke keer nogal eng daarboven. Op een dag durfde je echt niet meer verder omhoog. Vandaag vraagt een vriend(in) naar je ervaringen: "Wat was je aan het doen die dag?". Je vertelt: 


\section{M. Flecken}

a) Ik klom maar ik durfde niet meer verder

b) Ik was aan het klimmen maar ik durfde niet meer verder

$1-2-3-4-5$

'Imagine: Last summer you were in Canada to climb mountains. It was a great experience, although each time you reached the summit it was rather frightening. One day you were really too afraid to climb any further. Today a friend asks about your experiences: "What were you doing that day?"

a) I climbed but I was too afraid to continue

b) I was at-the-climb but I was too afraid to continue'

28) Stel: Elke zondag is er voetbal op tv. Je bent een enorme fan van een van de clubs in de Eredivisie: AZ. Tijdens elke wedstrijd van die club duim je voor een overwinning. Je broer ziet nu dat je zenuwachtig bent en vraagt: "Wat doe jij toch elke zondag?". Je vertelt hem:

a) Ik hoop dat AZ wint!

b) Ik ben aan het hopen dat $A Z$ wint!

$1-2-3-4-5$

'Imagine: Every Sunday, football is being broadcasted on television. You are a big fan of one of the teams in the Premier League: AZ . . During every match this club plays you are hoping for victory. Your brother now notices your exitement and he asks: "What do you do each Sunday?" You tell him:

a) I hope that $\mathrm{AZ}$ wins!

b) I am at-the-hope that AZ wins!'

29) Stel: Je hebt dit weekend een surfcursus in Zandvoort. De hele dag ben je eigenlijk wel op het strand en in het water te vinden. Tussen twee lessen door word je gebeld op je mobieltje en iemand stelt je de vraag: "Wat ben je nu aan het doen?". Je vertelt:

a) Ik ben aan het surfen

b) Ik surf

$1-2-3-4-5$

'Imagine: This weekend, you are taking part in a surfing course in Zandvoort. All day long you are to be found on the beach and in the water. In between classes you receive a phonecall on your mobile and somebody asks you the question: "What are you doing right now?" You tell him/her:

a) I am at-the-surf

b) I surf'

30) Stel: Elke zaterdagmiddag ga je in een zwembad baantjes trekken. Op een dag vraagt een collega je of je zin hebt om zaterdagmiddag naar de stad te gaan. Hijl vraagt: "Wat doe je normaal op zaterdagmiddag?" Je vertelt hem/haar:

a) ik ben aan het zwemmen

b) ik zwem

$1-2-3-4-5$

'Imagine: Every Saturday afternoon you go to a swimming pool to swim. One day a colleague asks whether you would like to go into town with him/her next Saturday 
afternoon. He/she asks: "What do you normally do on a Saturday afternoon?". You tell him/her:

a) I am at-the-swim

b) I swim'

31) Stel: Vorig jaar logeerde je kleine nichtje een tijdje bij jullie. Zij wilde toen de hele week alleen maar tekenen, samen met jou. Haar pronkstuk was een grote tekening van een felgekleurd mannetje. Nu vertelt ze over dit logeerpartijtje aan opa en oma. Je oma vraagt je nichtje: "Wat was je aan het doen vorig jaar in de vakantie?". Ze zegt:

a) Ik was een heel mooi poppetje aan het tekenen

b) Ik tekende een heel mooi poppetje/Ik heb een heel mooi poppetje getekend $1-2-3-4-5$

'Imagine: Last year your little cousin was staying at your house for a while. All she wanted to do all week was to make drawings, together with you. Her masterpiece was a large drawing of a brightly colored puppet. Now she is telling her grandparents all about this little trip. Your grandmother asks your cousin: "What were you doing last year on holidays?" She explains:

a) I was a very nice puppet at-the-draw

b) I drew a very nice puppet'

32) Stel: Je moet voor school/studie een enorm werkstuk schrijven, en dit moet volgende week af zijn. Je werkt er trouw elke dag aan. Een vriendin die je lang niet gezien hebt, belt je op. Ze vraagt: "Wat ben je elke dag aan het doen?" Je vertelt haar:

a) Ik ben een werkstuk aan het maken

b) Ik maak een werkstuk

$1-2-3-4-5$

'Imagine: For school you have to write an assignment, and this has to be finished by next week. You work on it with dedication every day. A friend, whom you have not seen for a long time, rings you up. She asks you: "What are you doing each day?" You tell her:

a) I am an assignment at-the-make

b) I make an assignment'

33) Stel: Vorige maand zat je op een vrijdag nog tot zeven uur op je werk. Daardoor miste je de trein naar een vriendin die je dat weekend wilde bezoeken. Nu vertel je een van je collega's dat je baalt dat je toen je leuke weekendje gemist hebt. Iemand vraagt waarom je dan je trein miste: "Wat deed je die vrijdag dan zo laat nog?" Je antwoordt:

a) Ik at nog even snel mijn boterham op/Ik heb nog even snel mijn boterham opgegeten

b) Ik was nog even snel mijn boterham aan het opeten

$1-2-3-4-5$

'Imagine: On a Friday last month you stayed at work until 7 o'clock in the evening. Because of this, you missed the train to go to a friend, whom you would have liked to visit that weekend. Now you are telling one of your colleagues about that situation and that you are sad you missed out on a fun weekend. Somebody asks why you missed the train that night: "What did you do that late that Friday?" You answer: 
a) I ate my sandwich quickly

b) I was quickly my sandwich at-the-eat'

34) Stel: Je vindt je woning al een tijdje niet meer mooi. Vandaag besluit je er wat aan te gaan doen. In de winkel zoek je een mooie kleur verf en wat leuke accessoires uit, en eenmaal thuis ga je aan de slag. Het blijkt nog een flinke klus te zijn! Na een paar uur gaat je telefoon. Een vriend vraagt: "Wat ben je nu aan het doen?"

a) Ik verander mijn interieur

b) Ik ben mijn interieur aan het veranderen

\section{$1-2-3-4-5$}

'Imagine: You are not too fond of your apartment and this has been the case for a while now. Today you decide to do something about it. You pick out a nice colour paint in the shop and some nice accessories and, once at home, you start working. It turns out to be quite a job! After a few hours your phone rings. A friend asks: "What are you doing?".

a) I change my interior

b) I am my interior at-the-change'

35) Stel: Vorig jaar heb je een klein ongelukje gehad met een mes tijdens het snijden van een komkommer. Nu ziet iemand het litteken op je vinger en vraagt dus aan je hoe je die wond hebt gekregen: "Wat was je aan het doen vorig jaar?" Je vertelt:

a) Ik was een komkommer aan het snijden

b) Ik sneed een komkommer/Ik heb een komkommer gesneden

$1-2-3-4-5$

'Imagine: Last year you had a little accident with a knife, while cutting a cucumber. Now somebody has spotted the scarf on your finger and asks how you received the wound: "What were you doing last year?" You tell them:

a) I was a cucumber at-the-cut

b) I cut a cucumber'

36) Stel: Vorige maand heb je op een regenachtige dag binnengezeten en een beeld geboetseerd. Je huiskamer lijkt nu wel een galerie! Iemand vraagt: "Wat deed je vorige maand?"

a) Ik was een beeld aan het boetseren

b) Ik boetseerde een beeld|Ik heb een beeld geboetseerd

$1-2-3-4-5$

'Imagine: Last month you sat inside on a rainy day and you moulded a statue. Your apartment now looks like an art exhibition hall! Somebody asks: "What did you do last month?"

a) I was a statue at-the-mould

b) I moulded a statue'

37) Stel: Je staat in de keuken, en bent bezig met de afwas. Terwijl je bezig bent roept iemand vanuit de andere kamer: "Wat doe je nu?" Je roept terug:

a) Ik was een pan af

b) Ik ben een pan aan het afwassen

$1-2-3-4-5$ 
'Imagine: You are in the kitchen, busy doing the dishes. While working, somebody calls at you from the other room: "What do you do now?" You call back:

a) I wash up a pan

b) I am a pan at-the-washing up'

38) Stel: Je houdt niet zo van koken. Elke avond na het werk kom je thuis en eet je soep, pasta of groenten uit blik. Tijdens de lunchpauze komt het gesprek een keer op koken, en iemand vraagt je: "Wat doe je normaal met eten?" Je vertelt:

a) Ik ben een blik open aan het maken

b) Ik maak een blik open

$1-2-3-4-5$

'Imagine: You are not too fond of cooking. Every evening after work you come home and eat a canned soup, pasta or vegetable dinner. During the lunch break today the conversation is about cooking, and somebody asks you: "What do you normally do for dinner?" You tell them:

a) I am a can at-the-open

b) I open a can'

39) Stel: Vorige maand was het erg rustig op het werk. Er was teveel personeel en je had dus niet veel te doen. Je besloot je toen maar te amuseren met een stuk papier. Helaas zag je baas het en zij vond het niet zo'n goede manier om werktijd door te brengen. $\mathrm{Nu}$ vraagt iemand je waarom de baas vorige maand boos op je was: "Wat deed je vorige maand?" Je vertelt:

a) Ik vouwde een vliegtuig/Ik heb een vliegtuig gevouwen

b) Ik was een vliegtuig aan het vouwen

\section{$1-2-3-4-5$}

'Imagine: Last month you had a quiet day at work. Too many members of staff were working so there was not much for you to do. You decided to kill time by playing around with a sheet of paper. Unfortunately, your boss spotted it and did not think it such a great way to pass time. Now a colleague is asking why the boss got angry with you: "What did you do last month?" You explain:

a) I folded an airplane

b) I was an airplane at-the-fold'

40) Stel: Je zit thuis achter de computer, als je ineens op een chatprogramma door een oude bekende wordt aangesproken. Jullie hebben het over vroeger en waar je op dit moment mee bezig bent. Hij/zij vraagt je iets over vorig jaar: "Wat was je vorig jaar aan het doen?" Je vertelt hem/haar:

a) Ik was nog niet klaar met school en woonde in Utrecht.

b) Ik was nog niet klaar met school en was in Utrecht aan het wonen.

$1-2-3-4-5$

'Imagine: You are at home, sitting at your computer, and all of a sudden an old friend starts chatting with you. You talk about old times and about the things you are doing right now. He/she asks a question about what you have been doing last year: "What were you doing last year?" You tell him/her:

a) I hadn't finished school yet and lived in Utrecht

b) I hadn't finished school yet and was in Utrecht at-the-live' 


\section{Notes}

1. This study was funded by the DFG. Many thanks for their financial support. I would like to thank Mary Carroll, Christiane von Stutterheim and Barbara Schmiedtová for helpful comments on earlier versions of this manuscript. I am also grateful to two anonymous reviewers for their helpful suggestions on two earlier drafts of the paper. Correspondence address: Institut für Deutsch als Fremdsprachenphilologie, Universität Heidelberg, Plöck 55, 69117 Heidelberg, Germany. E-mail: flecken@idf.uni-heidelberg.de.

2. It is also claimed that the process is more complicated and the present day-ing progressive evolved out of two separate forms, one being the above mentioned locative construction, the other one being a combination of 'to be' and a present participle (ending in-ende). The latter form stems from Old English and merged with the former one in Middle English (see e.g., Elsness 1994).

3. Clearly, the linguistic category of grammatical aspect must be carefully distinguished from lexical means that function to express different temporal perspectives on events, such as adverbials or complex verb constructions (see also Schmiedtová and Flecken 2008).

4. The studies were carried out in a joint research project with Marianne Starren at the Radboud University, Nijmegen, in close cooperation with the group of Christiane von Stutterheim and Mary Carroll at the University of Heidelberg.

5. Within the Type B situations with an affected object there are items that express a relatively long and those that express a relatively shorter duration. This variable was currently left out of the analyses. Future studies will include the variable duration and control for it more systematically across the variety of situation types.

6. Even though situations typically expressed by 0 -state verbs (states) constitute the least prototypical situation type to be combined with an aan het-construction, it makes no sense to extend the duration of 0 -states such as to know for they inherently imply unbounded duration.

7. The choice always involves a binary opposition between a predicate with the simple verb form and a predicate marked with an aan het form. Although in Dutch there are other possibilities to explicitly express the ongoingness of a situation, an elicitation study (von Stutterheim et al. 2009, see 1.2) has shown that, in Dutch, the aan het-construction is the clearly preferred means amongst the variety of options.

8. The data for the acceptability judgments made for the form not chosen will not be part of the focus of the paper.

9. In some cases, the predicate requires a specification in the form of a verbal complement as in Ik woon in Utrecht/Ik ben in Utrecht aan het wonen (I live in Utrecht) or Ik heb een hondIIk ben een hond aan het hebben (I have a dog). Leaving this out, would make both options unacceptable.

10. There were no gender-related differences in the number of choices for aan het versus the simple form throughout the task.

11. The total number of answers chosen (and acceptability judgments made) does not amount to exactly 42 answers per subject: Cases of incompletely filled in judgment tasks were treated as 'missing data' in the statistical analyses.

12. In the current study, two-tailed z-tests were used to compare proportions between independent samples. Within-group comparisons (e.g., a comparison of the number of choices for aan het between situation types or temporal contexts) were done by means of chi square tests.

13. The asterisks in the figures indicate statistically significant differences between specific groups.

14. In von Stutterheim et al. (2009), however, Dutch speakers show a preference for using the aan het-construction more frequently when describing Type B situations that show homoge- 
neous subevents, rather than Type A situations: Use of aan het in Type A situations is $43.71 \%$ vs. Type B situations with homogeneous subevents $63.16 \%$ (Carroll et al. 2008; von Stutterheim et al. 2009). In speech production, use of aan het is thus more likely to occur when describing situations showing progression towards a qualitative change of an entity (Type B situations), with homogeneous subevents, rather than situations that show no progression (Type A, swim, surf, etc).

\section{References}

Bertinetto, Pier Marco, Karen H. Ebert \& Casper de Groot. 2000. The progressive in Europe. In Östen Dahl (ed.), Tense and aspect in the languages of Europe, 517-558. Berlin \& New York: Mouton de Gruyter.

Boogaart, Ronny. 1991. "Progressive Aspect" in Dutch. In Frank Drijkoningen \& Ans van Kemenade (eds.), Linguistics in the Netherlands, 1-9. Amsterdam \& Philadelphia: John Benjamins.

Boogaart, Ronny. 1999. Aspect and temporal ordering. A contrastive analysis of Dutch and English. The Hague: Holland Academic Graphics.

Booij, Gerard. 2008. Constructional idioms as products of linguistic change: the aan het + infinitive construction in Dutch. In Alexander Bergs \& Gabriele Diewald (eds.), Constructions and Language Change, 79-104. Berlin \& New York: Mouton de Gruyter.

Bybee, Joan, Revere Perkins \& William Pagliuca.1994. The Evolution of Grammar: Tense, aspect and modality in the languages of the world. Chicago: University of Chicago Press.

Bybee, Joan. 1994. The grammaticization of zero. In William Pagliuca (ed.), Perspectives on grammaticalization, 235-254. Amsterdam \& Philadelphia: John Benjamins.

Carroll, Mary, Christiane von Stutterheim \& Ralph Nüse. 2004. The language and thought debate: a psycholinguistic approach. In Christopher Habel \& Thomas Pechmann (eds.), Approaches to language production, 183-218. Berlin \& New York: Mouton de Gruyter.

Carroll, Mary, Silvia Natale \& Marianne Starren. 2008. Acquisition du marquage du progressif par des apprenants germanophones de l'italien et néerlandophones du français. AILE. 31-50.

Comrie, Bernard. 1976. Aspect: An introduction to the study of verbal aspect and related problems. Cambridge: Cambridge University Press.

Ebert, Karen. 2000. Progressive markers in Germanic languages. In Östen Dahl (ed.), Tense and aspect in the languages of Europe, 605-653. Berlin \& New York: Mouton de Gruyter.

Elsness, J. 1994. On the progression of the progressive in early Modern English. ICAME Journal 18. 5-25.

Flecken, M. (2010). Event conceptualization in language production of early bilinguals. LOT dissertation series 256. Utrechi: Igitur.

Givón, Talmy. 1973. The time-axis phenomenon. Language 49(4). 890-925.

Heine, Bernd, Ulrike Claudi, \& Friederike Hünnemeyer. 1991. Grammaticalisation: A conceptual framework. Chicago: University of Chicago Press.

Hopper, Paul \& Elizabeth Traugott. 2003. Grammaticalization. Cambridge: Cambridge University Press.

Jespersen, Otto. 1954. A modern grammar of English on historical principles, vol. 4: Syntax, part 3: Time and tense. London: Allen and Unwin.

Klein, Wolfgang. 1994. Time in Language. London: Routledge.

König, Ekkehard \& Johan van der Auwera. 1994. The Germanic languages. London: Routledge.

Leech, Geoffrey. 2004. Meaning and the English verb. Harlow: Pearson UK.

Lemmens, Maarten. 2005. Aspectual posture verb constructions in Dutch. Journal of Germanic Linguistics 17(3). 183-217. 
Leow, Ronald. 1996. Grammaticality judgment tasks and second language development. In James E. Alatis, Carolyn A. Straehle, Maggie Ronkin \& Brent Gallenberger (eds.), Georgetown University Round Table on Languages and Linguistics 1996: Linguistics, language acquisition, and language variation: Current trends and future prospects, 126-139. Washington, D.C.: Georgetown University Press.

Mandell, Paul. 1999. On the reliability of grammaticality judgment tests in second language acquisition research. Second Language Research 15(1). 73-99.

Natale, Silvia. 2009. Gebrauchsdeterminanten der verbalperiphrase stare + gerundio (Tübinger Beiträge zur Linguistik). Tübingen: Narr.

Schmiedtová, Barbara \& Monique Flecken. 2008. The role of aspectual distinctions in event encoding: Implications for second language acquisition. In Sabine de Knop \& Teun de Rycker (eds.), Cognitive approaches to pedagogical grammar, 357-384. Berlin \& New York: Mouton de Gruyter.

Sorace, Antonella. 2003. The use of acceptability judgments in second language acquisition research. In William Ritchie \& Tej Bhatia (eds.), Handbook of second language acquisition, 375-409. San Diego: Academic Press.

von Stutterheim, Christiane \& Mary Carroll. 2006. The impact of grammatical temporal categories on ultimate Attainment in L2 Learning. In Heidi Byrnes, Heather Weger-Guntharp \& Katherine Sprang (eds.), Educating for advanced foreign language capacities, 40-53. Georgetown: Georgetown University Press.

von Stutterheim, Christiane, Mary Carroll \& Wolfgang Klein. 2009. New perspectives in analyzing aspectual distinctions across languages. In Wolfgang Klein \& Ping Li (eds.), The expression of time, 195-216. Berlin \& New York: Mouton de Gruyter.

Vendler, Zeno. 1957. Verbs and times. The Philosophical Review, 66(2). 143-160.

Vlach, Frank. 1981. The semantics of the progressive. In Philip Tedeschi \& Annie Zaenen (eds.), Syntax and semantics, vol. 14: Tense and aspect, 271-291. New York: Academic Press. 